\author{
Research article \\ urn:1sid:zoobank.org:pub:3C501DE6-AC85-4199-8CDC-D28E42753050
}

\title{
Cochlostoma revised: the subgenus Lovcenia Zallot et al., 2015 (Caenogastropoda, Cochlostomatidae)
}

\author{
Enrico ZALLOT ${ }^{1, *}$, Zoltán FEHÉR ${ }^{2}$, Sonja BAMBERGER ${ }^{3}$ \& Edmund GITTENBERGER ${ }^{4}$ \\ ${ }^{1}$ Haagweg 29, NL-2681PA Monster, the Netherlands. \\ ${ }^{2}$ Hungarian Natural History Museum, Baross 13, 1088 Budapest, Hungary. \\ ${ }^{2,3}$ Natural History Museum Vienna, Burgring 7, 1010 Vienna, Austria. \\ ${ }^{4}$ Naturalis Biodiversity Center, P.O. Box 9517, NL-2300RA Leiden, the Netherlands. \\ *Corresponding author: ezallot@gmail.com \\ 2Email: feher.zoltan@nhmus.hu \\ ${ }^{3}$ Email: bambergerson@gmail.com \\ ${ }^{4}$ Email: egittenberger@yahoo.com

\footnotetext{
${ }^{1}$ urn:1sid:zoobank.org:author:365E17AD-6938-4364-A526-F1BDA2663E10

${ }^{2}$ urn:1sid:zoobank.org:author:E801EC76-8B1E-450B-993E-BBBE57C00EA9

${ }^{3}$ urn:1sid:zoobank.org:author:2EC5303E-6D8A-4AAC-AD64-C74ED5BA6C45

${ }^{4}$ urn:Isid:zoobank.org:author:D786C279-FC92-4D08-AF16-F79A9705E0AE
}

\begin{abstract}
Five species of the subgenus Lovcenia of Cochlostoma (Cochlostomatidae) are recognized, three of which are described as new to science: $C$. (L.) tropojanum sp. nov., C. (L.) jakschae sp. nov. and C. (L.) lanatum sp. nov. A lectotype is designated for C. (L.) erika (A.J. Wagner, 1906). The shell and the genital tracts are described for all species and the distributional data are summarized.
\end{abstract}

Keywords. Taxonomy, morphology, molecular phylogeny, the Balkans.

Zallot E., Fehér Z. Bamberger S. \& Gittenberger E. 2018. Cochlostoma revised: the subgenus Lovcenia Zallot et al., 2015 (Caenogastropoda, Cochlostomatidae). European Journal of Taxonomy 464: 1-25.

https://doi.org/10.5852/ejt.2018.464

\section{Introduction}

The most recent comprehensive revision of the genus Cochlostoma Jan, 1830 at the species level dates back to the end of the $19^{\text {th }}$ century (Wagner 1897). Since then, only restricted taxonomical contributions or revisions concerning species of limited geographical ranges have been published (e.g., Schütt 1977; Bank 1988; Fehér et al. 2001; Fehér 2004).

In a revision of the generic taxonomy of the Cochlostomatidae, Zallot et al. (2015) showed the applicability of genital characters complementary to the traditional conchological data in taxon diagnoses within this family. This approach, combined with the use of molecular phylogenetic methods, has opened new prospects in the taxonomy of Cochlostoma and formed the basis for a revised system at the generic and subgeneric level (Zallot et al. 2015). Using the same methods, the various subgenera of Cochlostoma will be dealt with in a series of articles. Here, a start is made with the subgenus Lovcenia Zallot et al., 2015. 


\section{Material and methods}

The locality data, summarized in Table 1, are also indicated for each species in the taxonomic section of this paper. The location of the sampling localities is indicated in Fig. 1. Pre-GPS samples are represented as an approximate position.

High resolution images of the shell specimens were made with a Canon EOS 600D camera with an EF-S

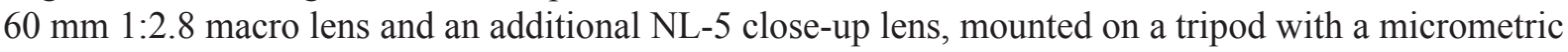
slide. Using Helicon Focus stacking software, several photographs were combined into a single picture. With the GIMP 2.6.11-GNU software, potentially diagnostic distances and angles were established (see Fig. 2). The distances were measured in pixels and then translated into metric measurements on the basis of the number of pixels per millimetre. This ratio was determined by comparing the height in pixels on the picture and the height in millimetres that was measured directly.

The number of whorls was counted on the photographs in frontal view. The apical whorl, because it is variable in size, was counted in tenths of the height of the whorl before the apical whorl. For convenience, the whorls are numbered from the basal (body whorl) up. Therefore, the $1^{\text {st }}$ whorl refers to the basal one.

\section{Heights}

The tip of the protoconch was aligned with the internal side of the columella visible in the left side of the aperture. The following heights were then measured on this main axis: total height (as above mentioned); height of the $1^{\text {st }}, 2^{\text {nd }}, 3^{\text {rd }}, 4^{\text {th }}$ whorls; height of the aperture between the highest point of the parietal lobe and the basis; height of the aperture along the main axis; height of the parietal lobe.

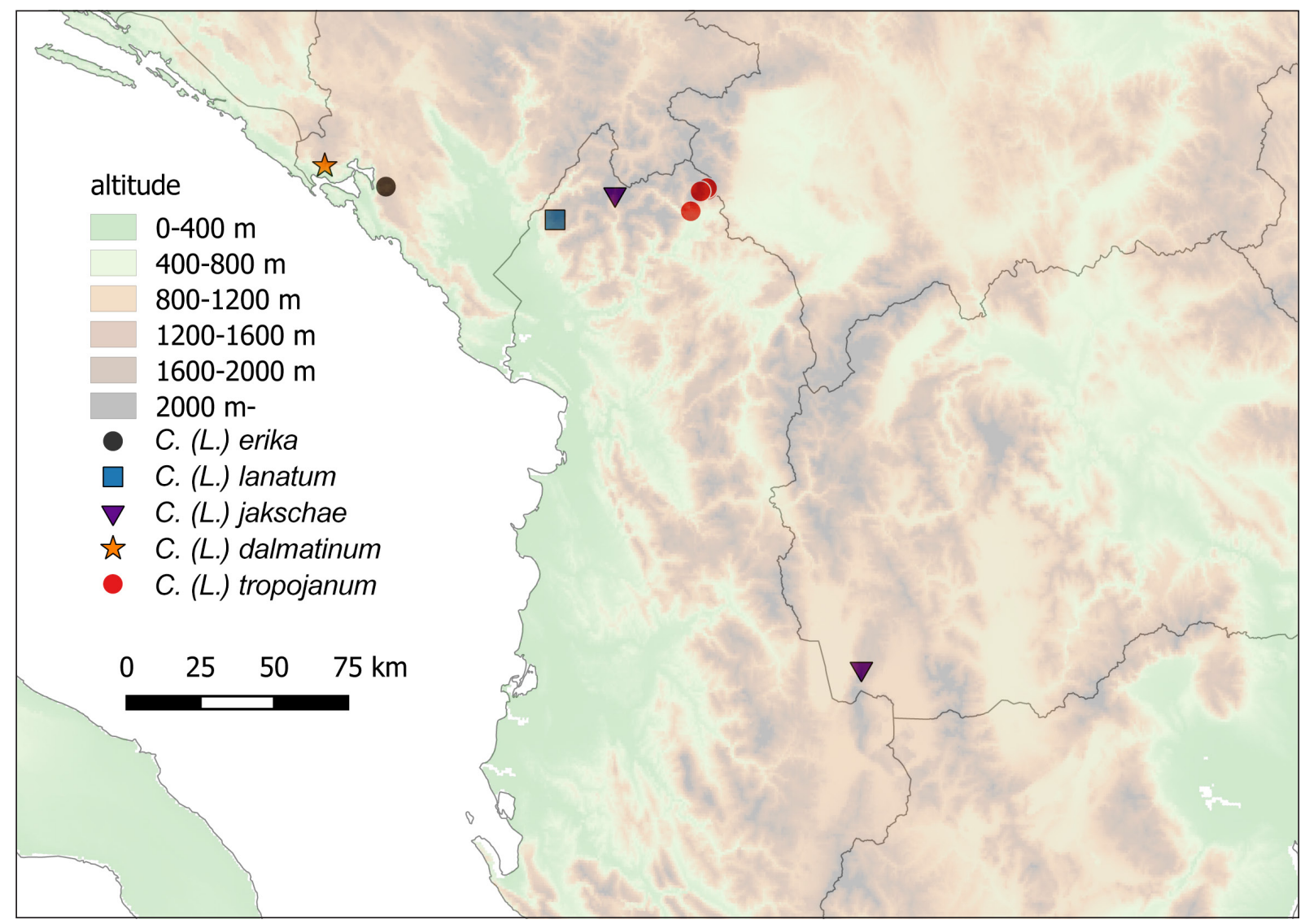

Fig. 1. Distribution of the species of Cochlostoma (Lovcenia) Zallot et al., 2015 in the western part of the Balkan Peninsula. 


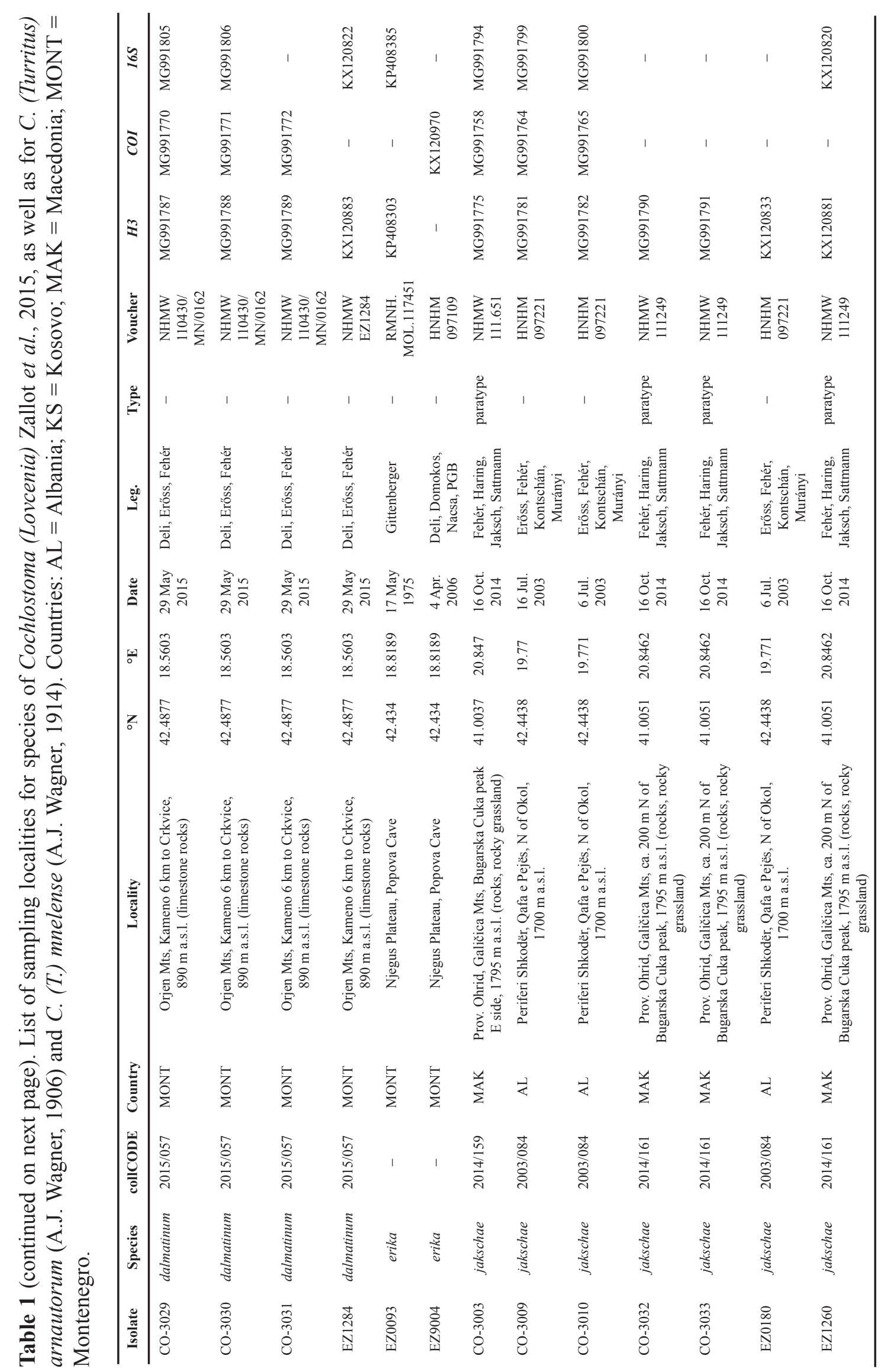




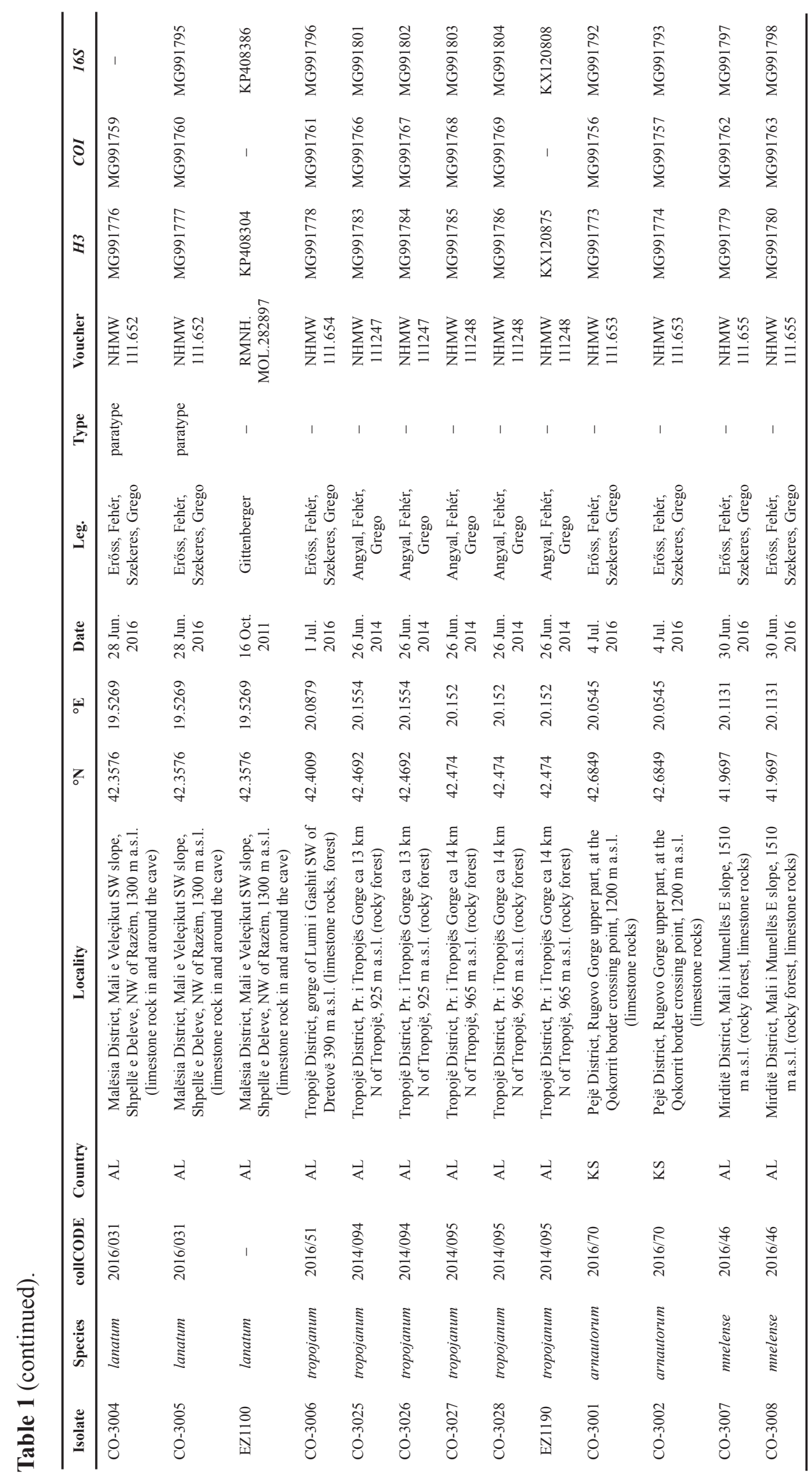




\section{Widths}

On a plane orthogonal to the main axis the following widths were measured: width of the basal whorl; width of the $2^{\text {nd }}$ whorl; width of the lower and upper suture of the $2^{\text {nd }}$ whorl; width of the basal protoconch whorl; width of the aperture; maximum width of the lips on the columellar side.

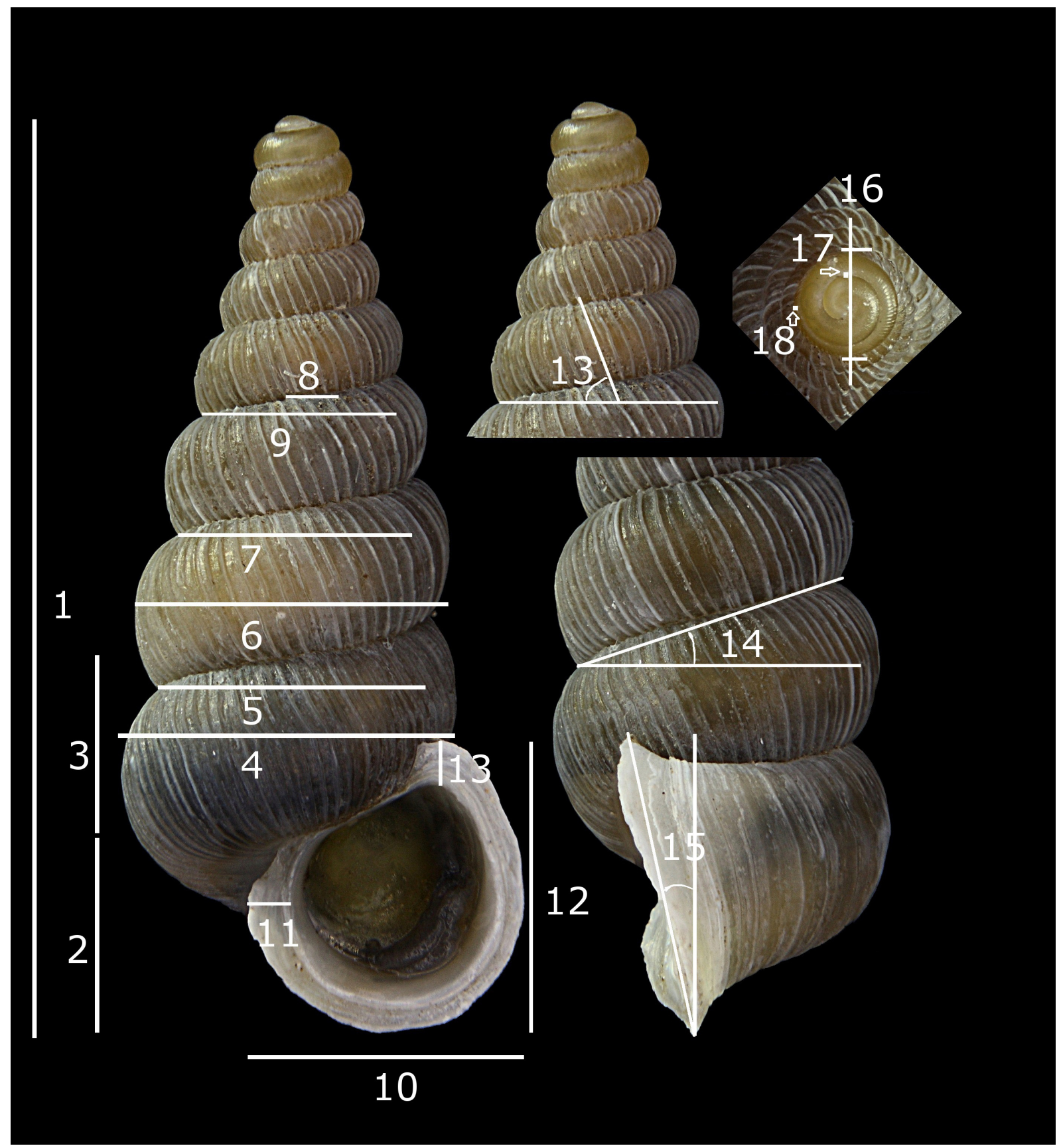

Fig. 2. Potentially diagnostic distances and angles. $1=$ shell height $(\mathrm{H}) .2=$ height of aperture at the columellar side. 3 = height of the first whorl. 4 = width of body whorl (Wbw). 5 = width of the suture above the body whorl. 6 = width of the penultimate whorl. 7 = width of the suture above the penultimate whorl. 8 = distance between the 5 most central ribs on the $4^{\text {th }}$ whorl up. $9=$ diameter of the $4^{\text {th }}$ whorl up. $10=$ aperture width (Wa). $11=$ width of the lip at the columellar side. $12=$ aperture height $(\mathrm{Ha})$. $13=$ rib inclination. $14=$ suture inclination. $15=$ aperture inclination. $16=$ protoconch diameter in upper view (Dp). $17=$ end of the smooth part of the protoconch. $18=$ end of the protoconch. 
The ratio between the width of the $2^{\text {nd }}$ whorl and the average width of the upper and lower sutures of the $2^{\text {nd }}$ whorl gives an index of the roundness of the whorl, a feature frequently mentioned in the description of the taxa within Cochlostoma. The ratio between the width of the $1^{\text {st }}$ and the $4^{\text {th }}$ whorl is an index of the slenderness of the shell.

\section{Ribs per $\mathrm{mm}$ and rib features}

The number of ribs per mm was calculated by measuring the distance between the first and the last of the most central 5 ribs of a whorl in frontal view. Because the ribbing is normally different in the apical rather than in the basal whorls, the measurement was repeated on the $1^{\text {st }}$ (taking the distance on the upper suture of the whorl) and on the $4^{\text {th }}$ whorl (taking the distance on the lower suture). Because the roundness of the $4^{\text {th }}$ whorl can distort the distances measured on the photograph, this distance (equal to the chord of the circumference) was translated to the distance along the arc.

The observed rib features (on the ribs of the $4^{\text {th }}$ whorl) were the following: type of ribbing (regular, irregular, double ribbing); shape of the ribs (sharp, rounded; straight or sinuous); height.

\section{Inclination of the ribs}

This was calculated taking the average of the inclination of the 3 most central ribs of the $4^{\text {th }}$ whorl and the most central rib of the $3^{\text {rd }}$ whorl with respect to the main axis. The angle between the main axis and the lower suture of the $4^{\text {th }}$ whorl was also recorded. In this way, the inclination of the ribs can be related either to the main axis or the suture itself.

\section{Inclination of the aperture}

In lateral view, the shell was moved into a standard position in order to have the basal point of the aperture aligned with the tip of the protoconch. Then, the angle between the lip of the aperture and the resulting main axis was measured. The inclination of the suture between the $1^{\text {st }}$ and the $2^{\text {nd }}$ whorl was also measured, allowing us to relate the inclination of the aperture to it.

To investigate the genital morphology, the lower whorls of the shells of male animals were removed in order to expose the right side of the foot. Shells of females were entirely removed. The body was then fixed in absolute ethanol. Females were positioned in such a way that the ventral side was visible at the level of the bursa copulatrix, between the $2^{\text {nd }}$ and the $3^{\text {rd }}$ whorls. In males, the mantle was cut vertically from the front up to the anus and, behind it, the tip of the prostatic gland. The anatomical details of individual specimens were figured with the help of a camera lucida and a stereo microscope. The description of the genitalia (see Fig. 3 for the terminology) begins with the structures that are located in the apical part of the body (i.e., the ovary or the testis). For more details, see Zallot (2002: 95-96) and Zallot et al. (2015).

List of abbreviations for material and shell characters:

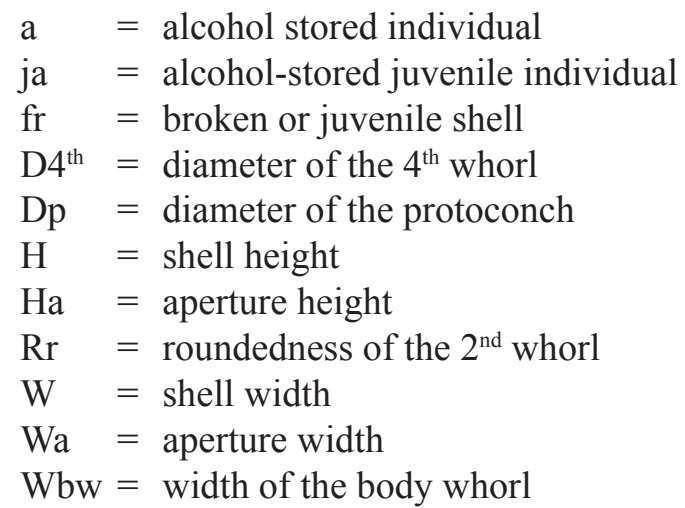


Institutional abbreviations used:

$\begin{array}{ll}\text { GR } & =\text { Private collection of J. Grego, Banska Bystrica, Slovakia } \\ \text { HNHM } & =\text { Hungarian Natural History Museum, Budapest, Hungary } \\ \text { NHMW } & =\text { Naturhistorisches Museum, Vienna, Austria } \\ \text { NHMW-E } & =\text { Edlauer collection in NHMW } \\ \text { NHMW-K } & =\text { Klemm collection in NHMW } \\ \text { RMNH } & =\text { Naturalis Biodiversity Center, Leiden, the Netherlands } \\ \text { SMF } & =\text { Naturmuseum Senckenberg, Frankfurt am Main, Germany }\end{array}$

In the 'Material examined' sections, the number of specimens is only provided for type material lots.

When Zallot et al. (2015) presented the first phylogenetic reconstruction for the genus Cochlostoma, only two species of Lovcenia were included, i.e., C. (L.) erika (A.J. Wagner, 1906) and the species described here as $C$. (L.) lanatum sp. nov. That study was based on only two markers, the nuclear Histone $H 3$ gene $(H 3)$ and the mitochondrial $16 S$ rRNA gene $(16 S)$. Due to the incomplete overlap of the available samples, the trees based on these two markers were calculated separately. In the present study, more taxa and more populations per taxon are included, and an additional marker, the mitochondrial cytochrome oxidase subunit I (COI) was used. The molecular analysis was performed on the basis of material from 13 different locations. Additionally, we used two populations of two different species belonging to the subgenus Turritus Westerlund, 1883.

The analysed specimens had either been kept in ethanol $70 \%$ or were dried animals, i.e., shells containing mummified bodies (Table 1). From specimens in ethanol, DNA was extracted with the DNeasy Blood
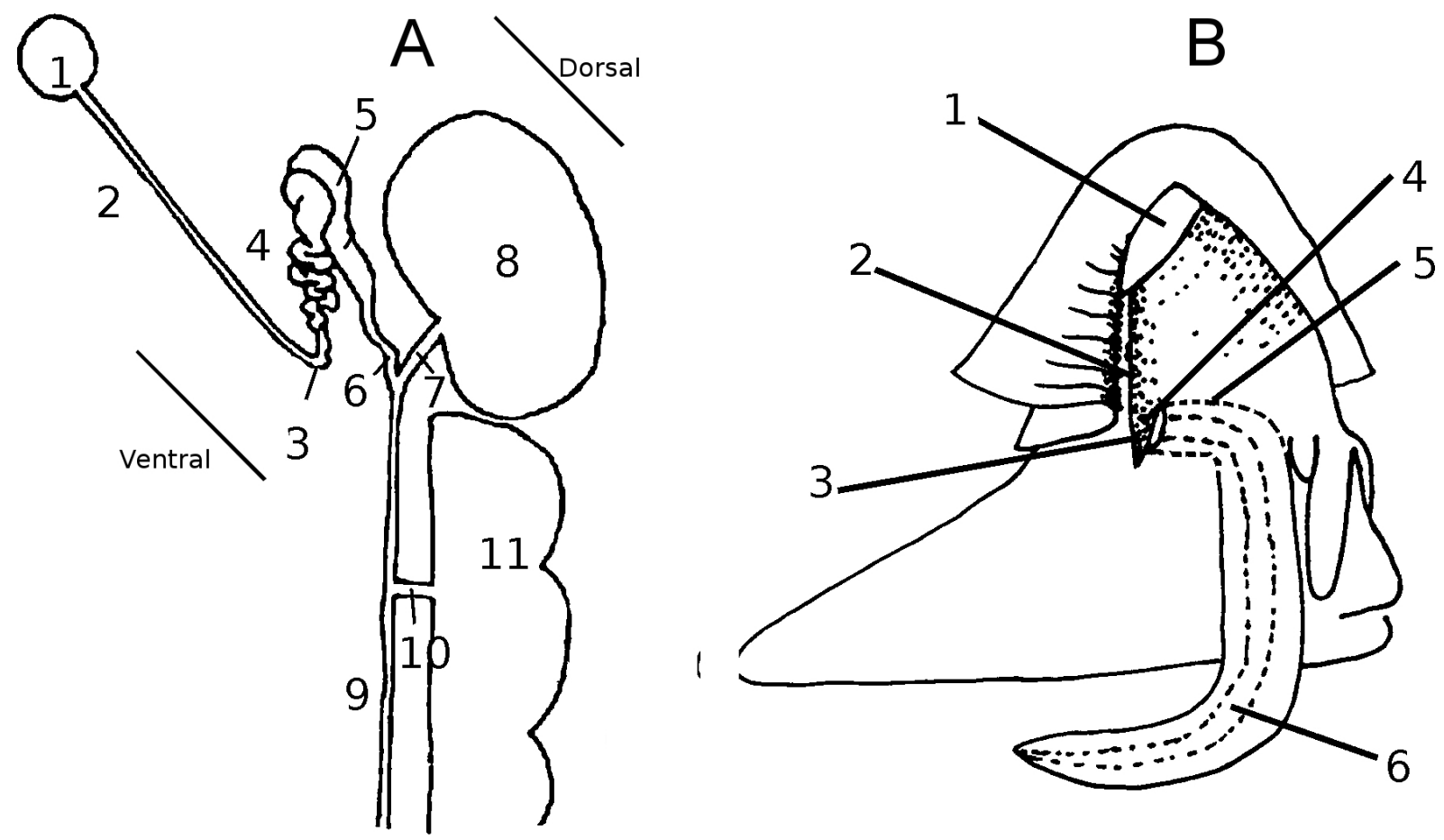

Fig. 3. Genitals of Cochlostoma Jan, 1830. A. Female genitals. $1=$ ovary; 2 = visceral oviduct; $3=$ proximal loop; $4=$ loops of the visceral oviduct; $5=$ seminal receptacle; $6=$ distal oviduct; 7 = pedunculus of the bursa copulatrix; $8=$ bursa copulatrix; $9=$ copulatory duct; $10=$ channel of the uterine gland; $11=$ uterine gland. $\mathbf{B}$. Male genitals. $1=$ anus; $2=$ groove fold; $3=$ sperm pocket; $4=$ penial funnel; $5=$ body spermiduct; $6=$ penis with the penial spermiduct. 
and Tissue Kit (QIAGEN, Hilden, Germany) following the manufacturer's protocol. Extraction and purification of DNA from mummified samples were done according to the method of Thomsen et al. (2009) modified for gastropods by Páll-Gergely et al. (2015). Fragments of the COI (658 bp), 16S (499$509 \mathrm{bp}$ ) and $H 3$ (309 bp) genes were amplified by polymerase chain reaction (PCR) using the following primers: 16SarF (Palumbi 1996) plus 16SLOrc_rev (Harl et al. 2014) for the 16S, HCO2198 (Folmer et al. 1994) plus COIschneckrev (Duda et al. 2011) for the COI and H3ColF (Colgan et al. 2000) plus H3PulR (Uit de Weerd \& Gittenberger 2013) for the H3. PCR protocols followed Harl et al. (2014) for $C O I$ and Páll-Gergely et al. (2015) for $16 S$ and $H 3$. Successfully amplified products were sequenced at LGC Genomics (Berlin, Germany). Sequences were assembled and edited using BioEdit ver. 7.0.1 (Hall 1999) and deposited in GenBank (Table 1).

Some previously published $H 3$ and $16 S$ sequences (Zallot et al. 2015, Table 1) were also used in the reconstruction of the phylogeny. $\mathrm{COI}$ and $\mathrm{H3}$ sequences could be unambiguously aligned manually. $16 S$ sequences were aligned with the online version of MAFFT (Katoh \& Standley 2013, http://mafft. cbrc.jp/alignment/software/) with the following settings: G-INS-i iterative refinement algorithm, gap opening penalty $=1.53$, offset value $=0.123$ and 'leave gappy regions'. This resulted in a $511 \mathrm{bp}$ long $16 \mathrm{~S}$ alignment. Thereafter, the three alignments were concatenated and divided initially into seven partitions. The ModelFinder function of IQ-Tree (Kalyaanamoorthy et al. 2017) selected the following partitioning scheme and best-fit models of sequence evolution according to the Bayesian Information Criterion (BIC): $H 31^{1 \text { st }}, 2^{\text {nd }}$ and $3^{\text {rd }}$ codon positions: $\mathrm{JC} ; C O I 1^{\text {st }}$ codon position: $\mathrm{TN}+\mathrm{F}+\mathrm{I} ; C O I 2^{\text {nd }}$ codon position: $\mathrm{F} 81+\mathrm{F}$; $\mathrm{COI} 3^{\text {rd }}$ codon position: $\mathrm{TVM}+\mathrm{F} ; 16 \mathrm{~S}: \mathrm{HKY}+\mathrm{F}+\mathrm{I}$. Phylogenetic relationships were estimated by employing a Maximum Likelihood-based (ML) method of tree reconstruction, as well as Bayesian Inference. ML tree reconstruction was done using IQ-TREE ver. 1.6.1 (Nguyen et al. 2015). Nodal supports were estimated by performing 1000 ultra-fast bootstrap repeats (Hoang et al. 2017), as well as employing the SH-aLRT test (Anisimova et al. 2011). All analyses, including model test, tree reconstruction and bootstrapping, were run on the W-IQ-TREE webserver (Trifinopoulos et al. 2016, http://iqtree.cibiv.univie.ac.at). An unconstrained Bayesian tree was inferred by MrBayes ver. 3.2.1 (Ronquist et al. 2012) using the following parameters: a four-chain (one cold, three heated; $\mathrm{T}=0.2$ ) Metropolis-coupled Markov chain Monte Carlo (MCMC) analysis, run for $5 \times 10^{6}$ generations; trees were sampled every 1000 generations and the first $10 \%$ of them was discarded as burn-in. Convergence of the Bayesian runs was checked with Tracer ver. 1.6 (Rambaut et al. 2014).

Genetic distances were calculated using MEGA ver. 6 (Tamura et al. 2013).

\section{Results}

We accept five species in Cochlostoma (Lovcenia), three of which are new to science. The molecular phylogenetic reconstruction, based on three markers $(H 3,16 \mathrm{~S}, \mathrm{COI})$, supports the monophyly of the subgenus Lovcenia as well as that of each species of Lovcenia.

At the same time, two different tree reconstruction methods resulted in partly incongruent topologies concerning relationships within the Lovcenia clade. Cochlostoma (L.) jakschae sp. nov. and $C$. (L.) tropojanum sp. nov. are sister taxa with high branch support in both of the trees. However, the relationships among the other three species are unclear: in the Bayesian tree $C$. (L.) dalmatinum (L. Pfeiffer, 1863) is in a basal position, in the ML tree C. (L.) erika is in that position (Fig. 4).

For the most widely used marker $(C O I)$, the uncorrected p-distances among conspecific populations vary from 0.015 (C. (L.) tropojanum sp. nov.) to 0.021 (C. (L.) jakschae sp. nov.), whereas it varies between species from 0.034 (C. (L.) jakschae sp. nov. and C. (L.) lanatum sp. nov.) to 0.087 for C. (L.) erika and C. (L.) dalmatinum) (Table 2). The subgenus is known from a relatively small range that includes W Montenegro, N Albania and W Macedonia. 


\title{
Taxonomy
}

\author{
Subclass Orthogastropoda Ponder \& Lindberg, 1996 \\ Superorder Caenogastropoda Cox, 1960 \\ Order Architaenioglossa Haller, 1890 \\ Superfamily Cyclophoroidea J.E. Gray, 1847 \\ Family Cochlostomatidae Kobelt, 1902 \\ Genus Cochlostoma Jan, 1830
}

Subgenus Lovcenia Zallot, Groenenberg, De Mattia, Fehér \& Gittenberger, 2015

Lovcenia Zallot, Groenenberg, De Mattia, Fehér \& Gittenberger, 2015: 80.

\section{Type species}

Auritus (Auritus) erika A.J. Wagner, 1906, by original designation.

\section{Diagnosis}

Shell slender conical, with more or less regularly spaced riblets, which may vary in prominence. Unlike the species of most subgenera of Cochlostoma, those belonging to Lovcenia can be distinguished conchologically, i.e., by the early ribbing of the protoconch, with fine riblets appearing already after

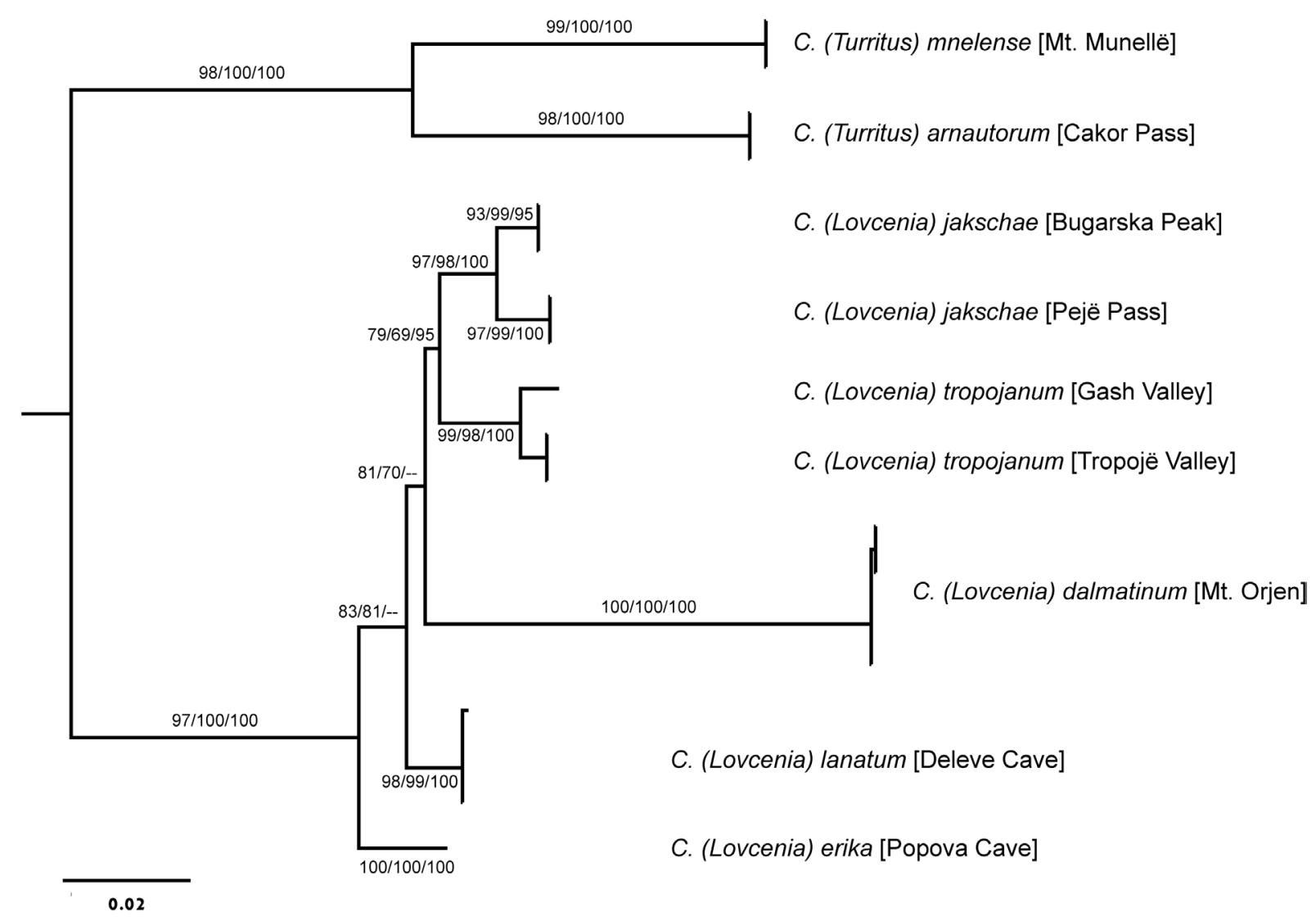

Fig. 4. Maximum Likelihood consensus tree of Cochlostoma (Lovcenia) Zallot et al., 2015 inferred from COI, $16 \mathrm{~S}$ rRNA and nuclear histone $H 3$ genes. Branch support values are: SH-aLRT support/ML ultrafast bootstrap support/Bayesian posterior probability percentage estimates. Note that two species of $C$. (Turritus) Westerlund, 1883 were used to define the root of the C. (Lovcenia) clade. 
Table 2. Estimates of evolution divergence between populations and species in Cochlostoma (Lovcenia) Zallot et al., 2015. Mean uncorrected COI p-distances are shown between species (in the lower half of the matrix) and between conspecific population (in the matrix axis).

\begin{tabular}{cccccc}
\hline & C. (L.) jakschae & C. (L.) deleve & C. (L.) tropojanum & C. (L.) dalmatinum & C. (L.) erika \\
\hline C. (L.) jakschae & {$[0.021]$} & & & & \\
C. (L.) deleve & 0.034 & {$[-]$} & & & \\
C. (L.) tropojanum & 0.036 & 0.035 & {$[0.015]$} & & \\
C. (L.) dalmatinum & 0.084 & 0.081 & 0.078 & {$[-]$} & \\
C. (L.) erika & 0.04 & 0.036 & 0.049 & 0.087 & {$[-]$} \\
\hline
\end{tabular}

its initial 0.3-0.5 whorl. In other taxa of Cochlostoma the protoconch is smooth for at least the initial 1.0-1.2 whorls. The female genitalia are characterized by the relatively large bursa copulatrix.

Cochlostoma (Lovcenia) erika (A.J. Wagner, 1906)

Figs $5 \mathrm{~A}, 6 \mathrm{~A}, 7-8$

Auritus (Auritus) erika A.J. Wagner, 1906: 132, pl. 4, fig. 15a-b.

Auritus (Auritus) erika - Kobelt 1907: 40, pl. 350, fig. 2178.

Cochlostoma erika - Jaeckel et al. 1957: 171. - Welter-Schultes 2012: 94.

Cochlostoma (Turritus) erika - Zilch 1958: 64. — Gittenberger 1976: 281, fig. 9.

Cochlostoma (Lovcenia) erika - Zallot et al. 2015: 80, figs 7-8, 13, 14.

\section{Diagnosis}

Cochlostoma (Lovcenia) erika differs from C. (L.) dalmatinum by the more regularly spaced and uniform ribs, which are larger and more variable in prominence in the latter species. It differs from C. (L.) jakschae sp. nov. and C. (L.) tropojanum sp. nov. by the indented, acutely curved columellar lobe, which is not gently curved inward, and from $C$. (L.) lanatum sp. nov. by the larger and more tumid shell with less prominent ribs.

\section{Material examined}

\section{Lectotype}

MONTENEGRO: "Popovo Höhle bei Njegus" [Popovo cave near Njeguš], 43.5291 N, 19.2074 E, 30 May 1903, Sturany leg. (NHMW 38260a). Here designated.

\section{Paralectotypes}

MONTENEGRO: 24 spec., same collection data as for lectotype (NHMW 38260b/10, NHMW 38469/6, NHMW-K 15368/4, NHMW 71640/O/8548/2, SMF 160854/2).

\section{Other material}

MONTENEGRO: same locality as lectotype but 1120 m a.s.l., Erőss and Fehér leg., 21 April 2000 (HNHM 86387); same locality as lectotype, Deli, Domokos, Nacsa and Páll-Gergely leg., 4 April 2006 (HNHM 97109); same locality as lectotype, Fuchs leg. (NHMW-K 47075); same locality as lectotype, Dabović leg. (NHMW-E 49343, NHMW-E 18270, NHMW-K 4447, NHMW-K 51886, NHMW-K 47074); Njeguš, karstic doline near a cave entrance, 900 m a.s.l., Jul. 1977, Maassen leg. (NHMW 81027); same locality as preceding, 17 May 1975, Gittenberger leg. (RMNH 117451); Duboki Do Cave near Krstac, Fuchs leg. (NHMW-E 28673, NHMW-K 15369, NHMW-K 8173). 


\section{Measurements}

Lectotype: H 9.5 mm, W 4.5 mm, Wbw 3.8 mm, Ha 3.6 mm, Wa 3.6 mm.

NHMW 38260b $(\mathrm{N}=6)$ and NHMW-K $47075(\mathrm{~N}=6)$ : H 8.9-10.1 mm, W 4.4-4.9 mm, Wbw 3.7-4.0 $\mathrm{mm}$, Ha 2.9-3.6 mm, Wa 3.1-3.7 mm.

\section{Description}

SHELl. Large, with $8 \frac{1}{2}-10$ whorls, H/W ratio 2.55 . The apical 2.4 whorls form the protoconch, which is smooth on only the initial 0.5 whorl; further on the whorls have fine, rather widely spaced riblets.

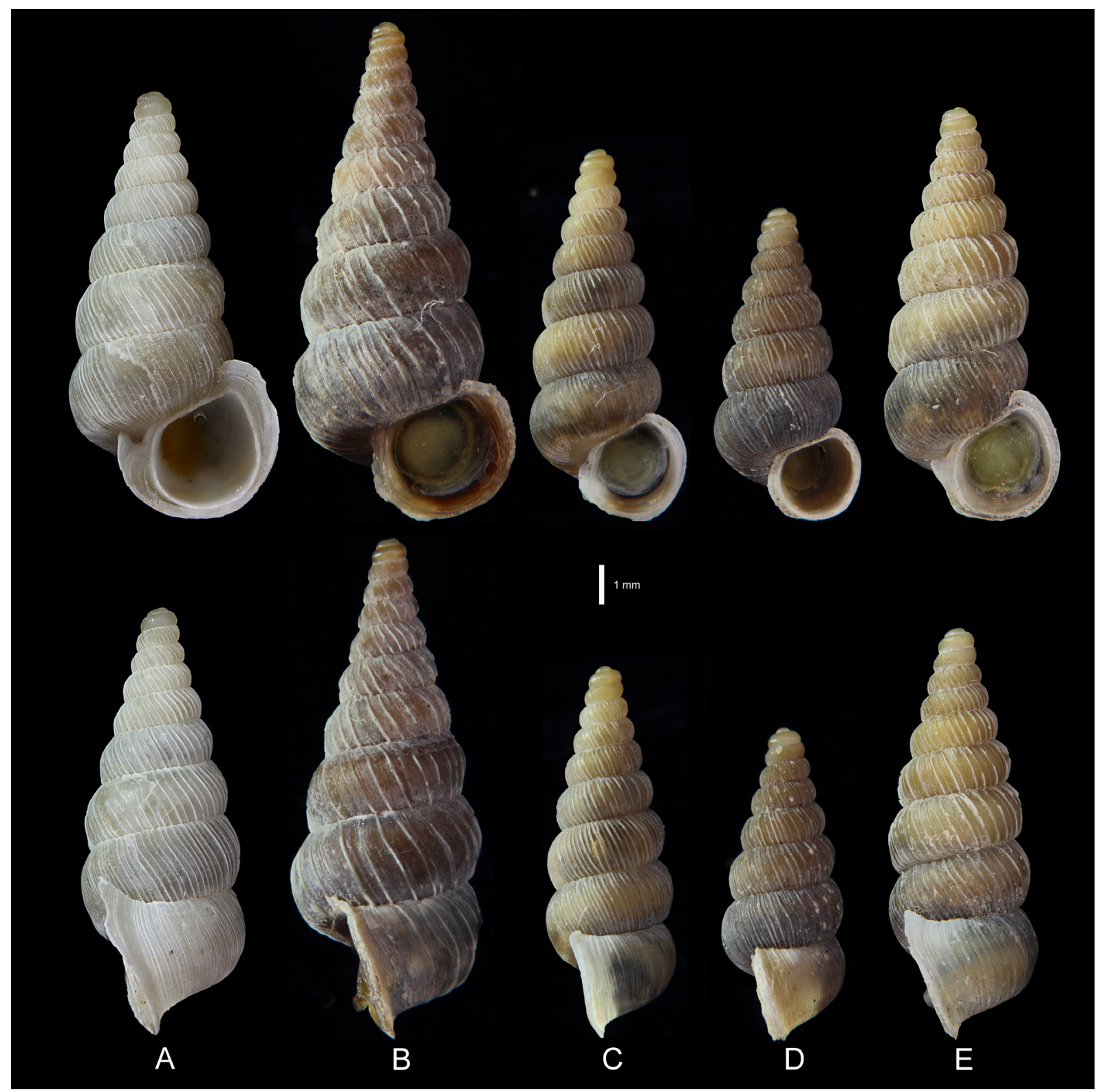

Fig. 5. Female specimens of Cochlostoma (Lovcenia) Zallot et al., 2015 used for anatomy (shells were destroyed before dissection). A. C. (Lovcenia) erika (A.J. Wagner, 1906) (HNHM 86387). B. C. (Lovcenia) dalmatinum (L. Pfeiffer, 1863) (NHMW 110430/MN/0162). C. C. (Lovcenia) tropojanum sp. nov. (NHMW 111248). D. C. (Lovcenia) jakschae sp. nov. (NHMW 111249). E. C. (Lovcenia) lanatum sp. nov. (HNHM 99861). 
The protoconch is relatively small, $\mathrm{Dp} / \mathrm{D} 4^{\text {th }} 0.55$. The shell is more or less light horn-brown, without spots. The teleoconch whorls are sculptured with whitish, rounded but thin ribs, which are uniform in height, spacing and shape; on the body whorl the ribs become more narrowly spaced and weaker while approaching the aperture. The aperture has a well-developed lip, which broadens at the columellar side before curving abruptly back, forming an acute angle and covering the umbilicus. The body whorl widens near the aperture.

FEMALE GenitaLia. Bursa copulatrix large, with a pedunculus connected proximally; its proximal lobe smaller than the distal one. Short seminal receptacle, without distal oviduct, confined to the ventral side of the body. Visceral oviduct nearly linear while running over the apex of the seminal receptacle. The junction of the uterine gland and the copulatory duct is far from the connection between the distal oviduct and the pedunculus of the bursa.

\section{Distribution}

This species lives on the Njeguši Plateau in Montenegro, where only two locations are known.

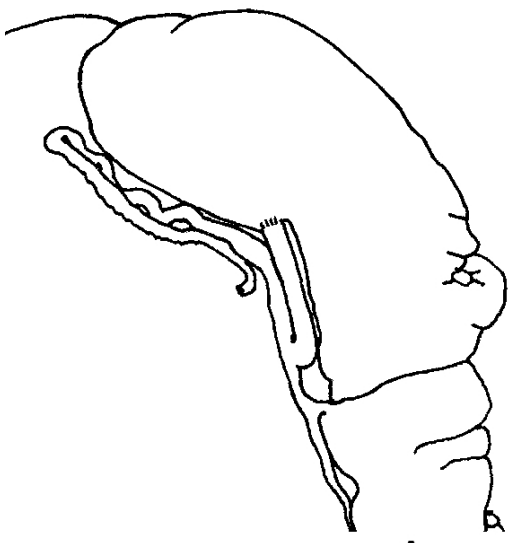

A

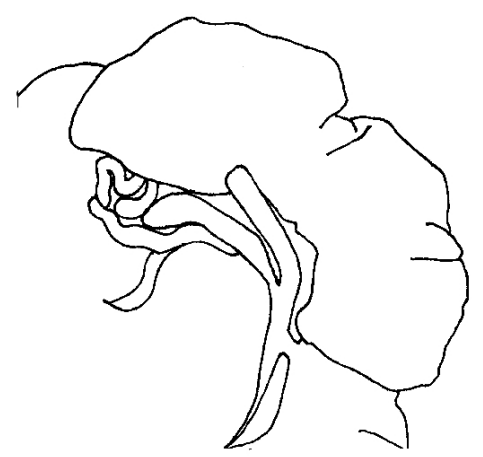

D1

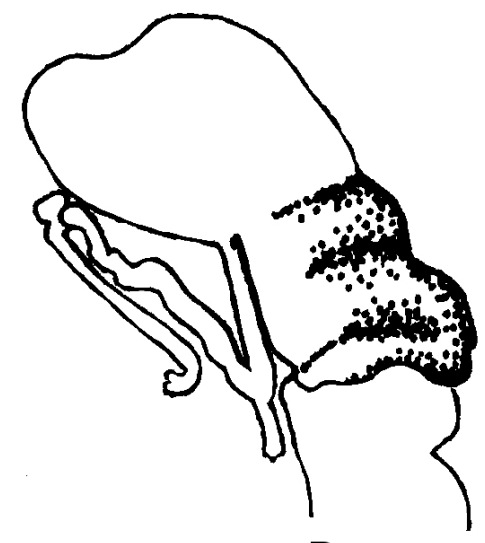

B

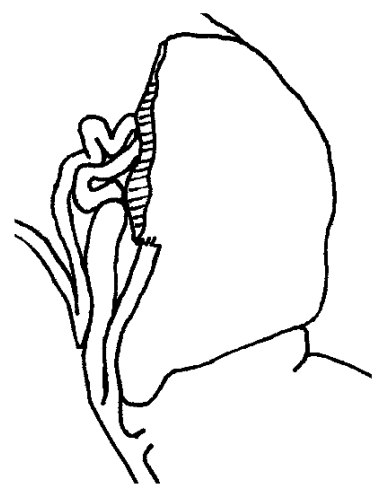

D2

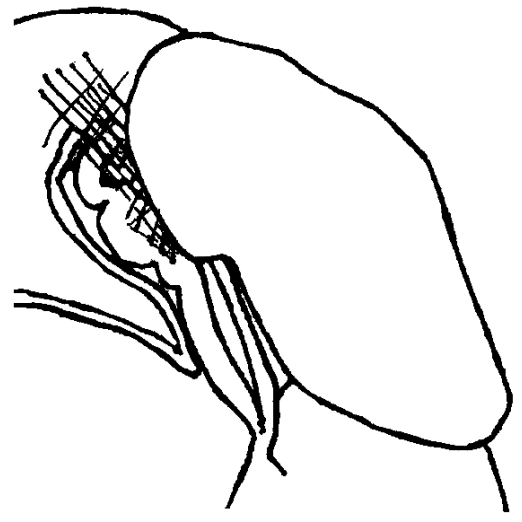

C

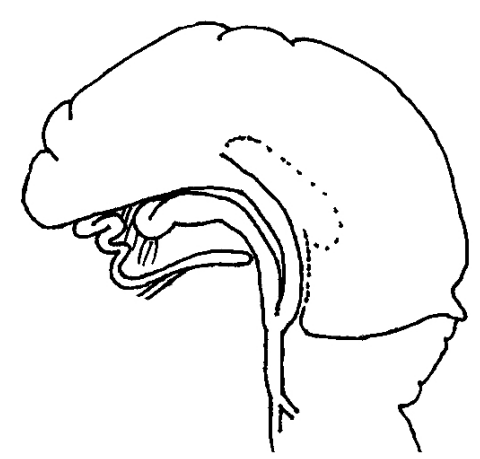

$E$

Fig. 6. Female genital morphology. See Table 1 for localities and Table 3 for measurements. A. Cochlostoma (Lovcenia) erika (A.J. Wagner, 1906) (HNHM 86387). B. Cochlostoma (Lovcenia) dalmatinum (L. Pfeiffer, 1863) (NHMW 110430/MN/0162). C. Cochlostoma (Lovcenia) tropojanum sp. nov. (NHMW 111248). D1. Cochlostoma (Lovcenia) jakschae sp. nov., Bugarska Peak population (NHMW 111249). D2. Cochlostoma (Lovcenia) jakschae sp. nov., Pejë Pass population (HNHM 97221). E. Cochlostoma (Lovcenia) lanatum sp. nov. (HNHM 99861). 
Table 3. Shell features of the analysed specimens of the 5 species of Cochlostoma (Lovcenia) Zallot et al., 2015.

\begin{tabular}{|c|c|c|c|c|c|c|c|c|c|c|c|c|c|c|c|c|c|c|c|c|}
\hline $\begin{array}{l}\text { \# } \\
\text { ¿े } \\
\stackrel{2}{2}\end{array}$ & 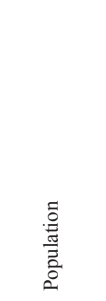 & $\begin{array}{l}\frac{\mathscr{y}}{\tilde{J}} \\
\ddot{0} \\
\dot{n}\end{array}$ & 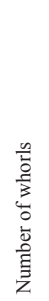 & 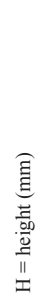 & 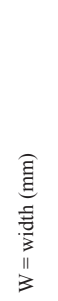 & 竞 & 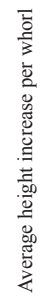 & $\underset{\widetilde{F}}{\mathbb{T}}$ & 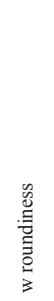 & 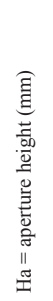 & 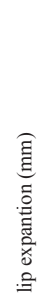 & 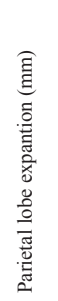 & 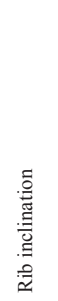 & 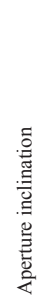 & 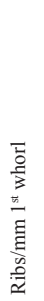 & 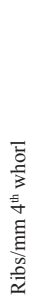 & 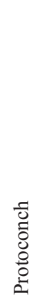 & 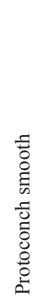 & 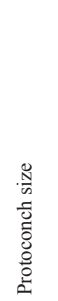 & 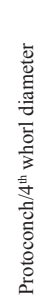 \\
\hline $\begin{array}{c}\text { NHMW110430/ } \\
\text { MN/0162 }\end{array}$ & Kameno & dalmatinum & 10.1 & 12.7 & 4.90 & 2.59 & 1.37 & 0.20 & 1.21 & 2.53 & 0.11 & 0.09 & 64.4 & 20.3 & 2 & 3 & 2.4 & 0.6 & 0.94 & 0.46 \\
\hline $\begin{array}{c}\text { NHMW110430/ } \\
\text { MN/0162 }\end{array}$ & Kameno & dalmatinum & 10.3 & 14.0 & 5.24 & 2.67 & 1.35 & 0.20 & 1.21 & 2.77 & 0.15 & 0.12 & 62.1 & 26.6 & 6 & 4 & 2.3 & 0.7 & 0.83 & 0.36 \\
\hline $\begin{array}{c}\text { NHMW 110430/ } \\
\text { MN/0162 }\end{array}$ & Orjen & dalmatinum & 10.1 & 13.0 & 4.85 & 2.68 & 1.37 & 0.20 & 1.21 & 2.58 & 0.15 & 0.15 & 60.4 & 15.5 & 2 & 4 & 2.5 & 0.6 & 0.99 & 0.46 \\
\hline $\begin{array}{c}\text { RMNH. } \\
\text { MOL.117451 }\end{array}$ & Crna Gora & erika & 9.0 & 10.8 & 4.20 & 2.57 & 1.38 & 0.22 & 1.18 & 2.36 & 0.22 & 0.21 & 63.5 & 21.0 & 5 & 5 & 2.4 & 0.5 & 1.00 & 0.56 \\
\hline HNHM86387 & $\begin{array}{l}\text { Popova } \\
\text { pecina }\end{array}$ & erika & 9.0 & 10.6 & 4.21 & 2.52 & 1.35 & 0.23 & 1.23 & 2.40 & 0.20 & 0.19 & 64.6 & 16.0 & 12 & 7 & 2.4 & 0.5 & 0.96 & 0.55 \\
\hline NHMW111249 & $\begin{array}{l}\text { Bukarsa } \\
\text { Cuka }\end{array}$ & jakschae & 7.8 & 7.9 & 3.26 & 2.42 & 1.36 & 0.22 & 1.23 & 1.73 & 0.13 & 0.10 & 66.2 & 17.2 & 9 & 10 & 2.4 & 0.7 & 0.91 & 0.73 \\
\hline NHMW111249 & $\begin{array}{l}\text { Bukarsa } \\
\text { Cuka }\end{array}$ & jakschae & 7.5 & 8.1 & 3.15 & 2.57 & 1.34 & 0.22 & 1.25 & 1.76 & 0.22 & 0.11 & 64.9 & 17.0 & 10 & 9 & 2.4 & 0.5 & 0.98 & 0.73 \\
\hline HNHM97221 & $\begin{array}{l}\text { Qafa e } \\
\text { Pejës }\end{array}$ & jakschae & 8.3 & 9.2 & 3.37 & 2.73 & 1.31 & 0.21 & 1.24 & 1.92 & 0.15 & 0.14 & 70.0 & 13.0 & 9 & 8 & 2.2 & 0.5 & 1.02 & 0.68 \\
\hline HNHM99861 & $\begin{array}{l}\text { Shellë e } \\
\text { Deleve }\end{array}$ & lanatum & 8.9 & 10.5 & 3.69 & 2.84 & 1.33 & 0.19 & 1.25 & 2.01 & 0.19 & 0.15 & 66.5 & 22.0 & 7 & 6 & 2.2 & 0.2 & 0.97 & 0.54 \\
\hline NHMW111248 & $\begin{array}{c}\text { Lumi I } \\
\text { Tropojës }\end{array}$ & tropojanum & 8.6 & 10.0 & 3.38 & 2.96 & 1.31 & 0.19 & 1.25 & 1.94 & 0.20 & 0.08 & 65.0 & 21.2 & 7 & 8 & 2.4 & 0.5 & 0.97 & 0.61 \\
\hline NHMW111248 & $\begin{array}{c}\text { Lumi I } \\
\text { Tropojës }\end{array}$ & tropojanum & 8.2 & 9.1 & 3.21 & 2.83 & 1.30 & 0.20 & 1.23 & 1.83 & 0.14 & 0.07 & 64.8 & 14.6 & 9 & 7 & 2.4 & 0.3 & 0.97 & 0.65 \\
\hline NHMW111248 & $\begin{array}{c}\text { Lumi I } \\
\text { Tropojës }\end{array}$ & tropojanum & 8.6 & 9.4 & 3.35 & 2.80 & 1.31 & 0.20 & 1.25 & 1.91 & 0.14 & 0.08 & 68.3 & 16.5 & 11 & 9 & 2.5 & 0.5 & 0.89 & 0.58 \\
\hline HNHM99865 & $\begin{array}{l}\text { Lumi I } \\
\text { Gashit }\end{array}$ & tropojanum & 8.5 & 9.2 & 3.30 & 2.79 & 1.31 & 0.21 & 1.25 & 1.93 & 0.13 & 0.10 & 67.0 & 16.0 & 8 & 5 & 2.1 & 0.3 & 0.92 & 0.60 \\
\hline HNHM99871 & Tropojë & tropojanum & 7.9 & 8.1 & 3.17 & 2.56 & 1.38 & 0.21 & 1.28 & 1.68 & 0.13 & 0.08 & 64.9 & 16.2 & 11 & 10 & 2.1 & 0.5 & 0.93 & 0.72 \\
\hline
\end{tabular}

\section{Habitat preference}

Like the majority of known Cochlostoma, this is an obligate rock-dwelling species. Although it can be found at Popovo Cave together with its congener Cochlostoma (Auritus) auritum (Rossmässler, 1837), this is not syntopy in the strict sense, because there is a difference in their niches. Cochlostoma (A.) auritum lives on the exposed rock surface around the cave entrance, whereas $C$. (L.) erika is found in the twilight zone inside the cave. Though little is known about its ecological requirements, C. (L.) erika is supposedly bound partly to the epigean environment (i.e., subtroglophile in the sense of Sket 2008).

\section{Remarks}

In order to promote nomenclatural stability, a female specimen, which was illustrated in the original description by Wagner (1906: fig. 15a-b), is herein designated as the lectotype.

Cochlostoma (Lovcenia) dalmatinum (L. Pfeiffer, 1863)

Figs 5B, 6B, 9

Pomatias dalmatinum L. Pfeiffer, 1863: 136-137.

Pomatias turritus Walderdorff, 1864: 508, 511. 
Pomatias (Auritus) dalmatinus - A.J. Wagner 1897: 620, pl. 9, fig. 95a-b.

Cochlostoma (Auritus) dalmatinum - Kobelt 1902: 518.

Auritus dalmatinus - A.J. Wagner 1906: 133.

Cochlostoma dalmatinum - Jaeckel et al. 1957: 171. — Zallot et al. 2015: 85.

Cochlostoma (Turritus) dalmatinum - Zilch 1958: 63, pl. 4, fig. 12.

\section{Diagnosis}

The irregular sculpture and its large shell height distinguish C. (L.) dalmatinum from other species of Cochlostoma (Lovcenia).

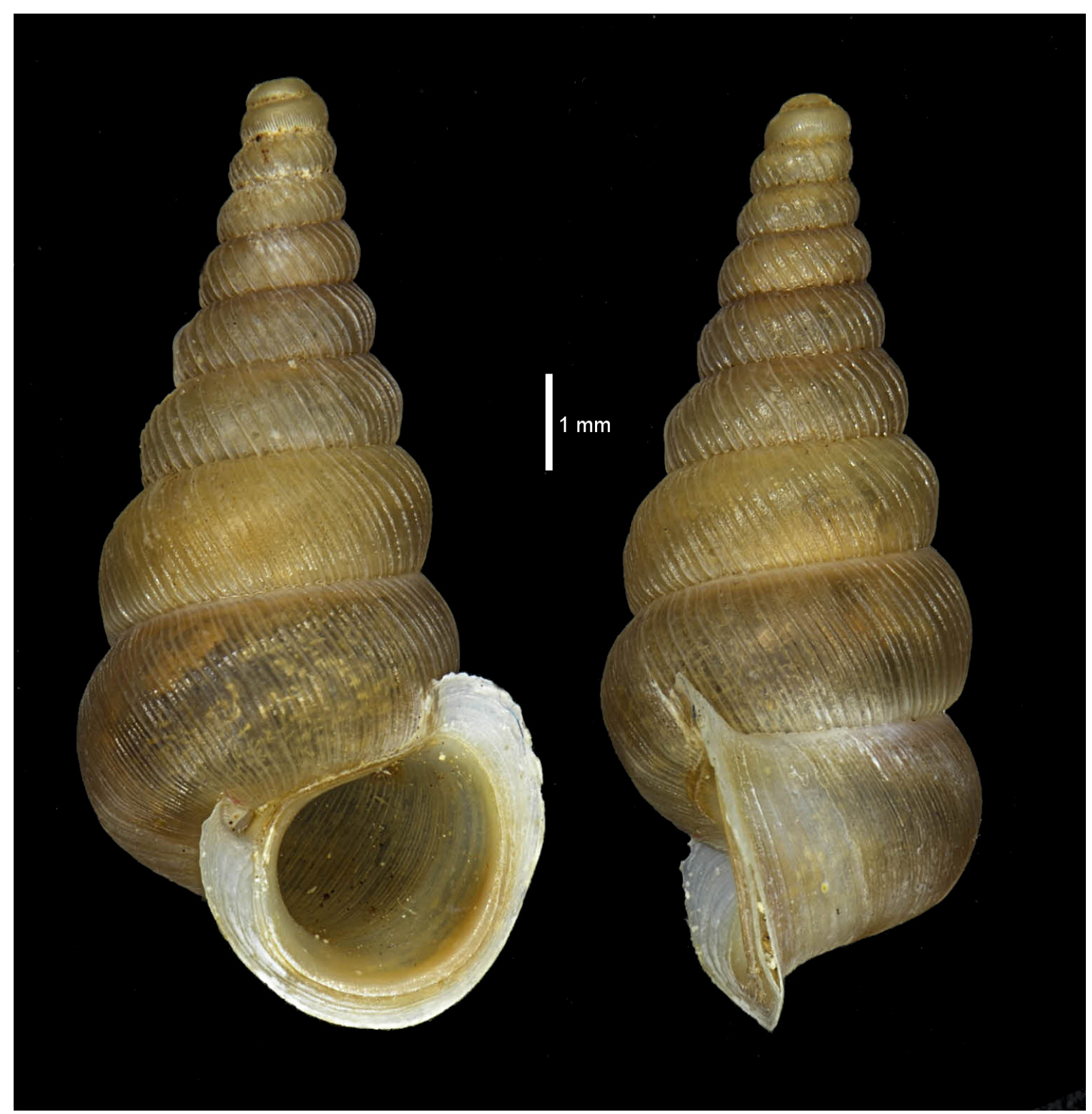

Fig. 7. Cochlostoma (Lovcenia) erika (A.J. Wagner, 1906), lectotype, "Popovo Höhle bei Njegus", Montenegro (NHMW 38260a). 


\section{Type material}

The type series from "Castel Nuovo Dalmatiae" (= Montenegro, Herceg-Novi) (L. Pfeiffer 1863: 136) was not available for study, but specimens from the type locality were compared (see below) as well as a photograph of a syntype (SMF 160850, ex coll. Parreyss) published by Zilch (1958: fig. 12).

\section{Material examined}

MONTENEGRO: Orjen Mts, Kameno, 6 km to Crkvice, $890 \mathrm{~m}$ a.s.1., $42.4877^{\circ} \mathrm{N}, 18.5603^{\circ} \mathrm{E}, 29$ May 2015, Deli, Erőss and Fehér leg. (NHMW 110430/MN/0162, HNHM 100133); 2 spec., Hercegnovi, Berg Radoštak, Mar. 1928, Käufel leg. (NHMW-K 15367); 5 spec., Radoštak at the source, Mar. 1928, Käufel leg. (NHMW-E 28682/1, NHMW-E 32879/2, NHMW-K 47084/2).

\section{Measurements}

HNHM $100133(\mathrm{~N}=12)$ : H 11.6-13.3 mm, W 5.3-5.8 mm, Wbw 4.4-4.8 mm, Ha 3.5-4.2 mm, Wa 3.6-4.1 mm.

\section{Description}

SHELL. Large, with many (10-11) whorls, H/W ratio 2.63. The apical 2.3-2.4 whorls form the protoconch, which is smooth only on the initial $0.6-0.7$ whorl and finely ribbed with closely spaced riblets further on. The protoconch is relatively small, i.e., $\mathrm{Dp} / \mathrm{D} 4^{\text {th }}=0.36-0.46$. The shell is more or less dark horn-brown, without spots. The teleoconch whorls are ribbed with whitish ribs that are irregular in height, spacing and shape. Between these main ribs, there are fine riblets, which have the same colour as the shell. There is no difference in rib distances between the upper whorls and the body whorl. The sculpture fades on the last part of the body whorl behind the aperture. The aperture is relatively small $(\mathrm{Ha} / \mathrm{H}=0.20)$, with an irregular lip. The lip enlarges on the columellar side before curving abruptly back and covering the umbilicus. The body whorl abruptly enlarges near the aperture, forming a moderately large external lobes.

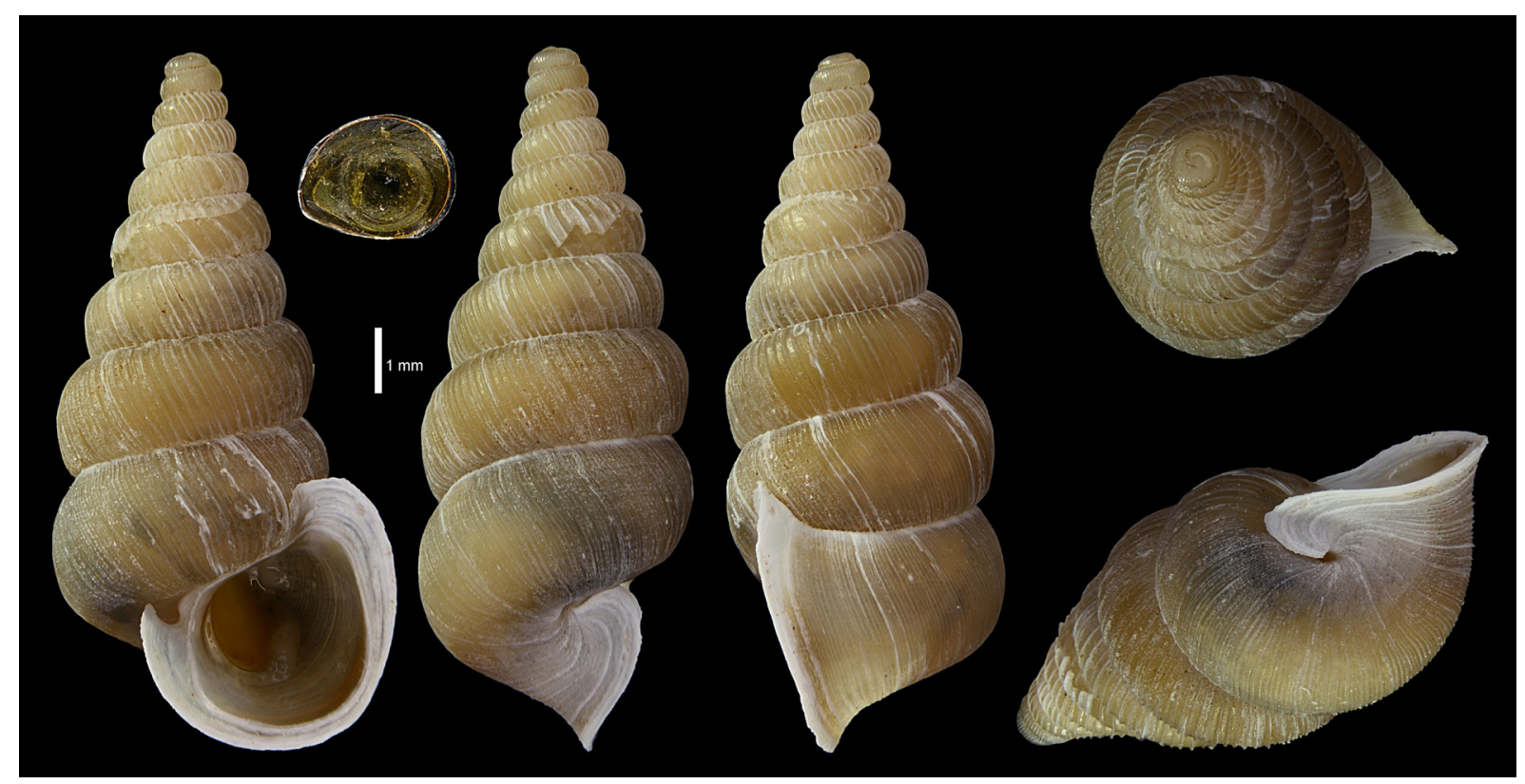

Fig. 8. Cochlostoma (Lovcenia) erika (A.J. Wagner, 1906), Popova Cave near Njeguš, Pljevlja, Montenegro (HNHM 86387). 
Female Genitalia. Large bursa copulatrix, with a pedunculus connected proximally; its proximal lobe smaller that the distal one. Short seminal receptacle, without distal oviduct and confined to the ventral side of the body. Loops of the visceral oviduct situated over the apex of the seminal receptacle. The junction of the uterine gland and the copulatory duct is situated far from the connection between the distal oviduct and the pedunculus of the bursa.

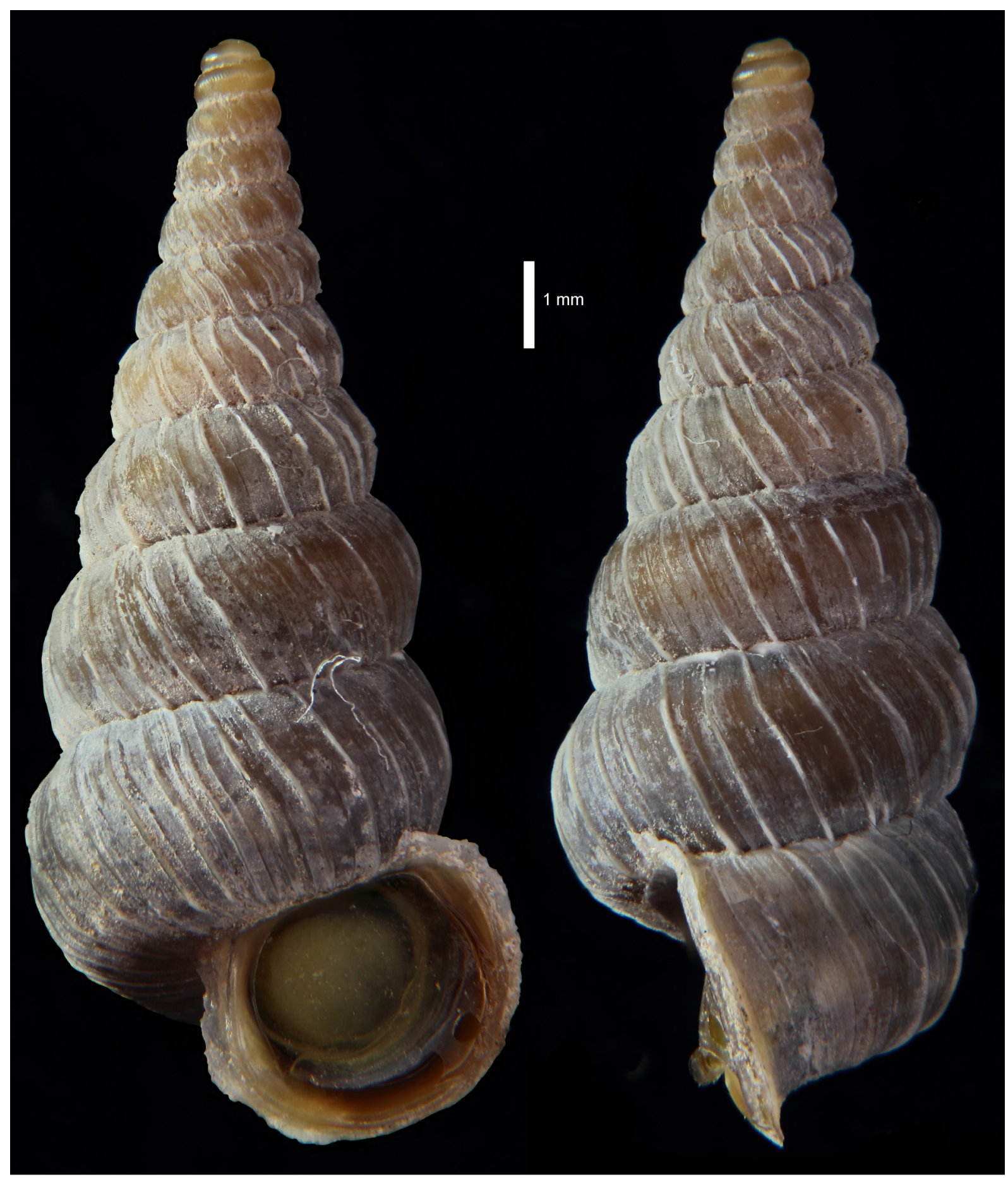

Fig. 9. Cochlostoma (Lovcenia) dalmatinum (L. Pfeiffer, 1863), Kameno, $6 \mathrm{~km}$ from Crkvice, Montenegro (NHMW 110430/MN/0162). 


\section{Distribution}

Northwest of the bay of Kotor in Montenegro. Wagner (1897) reported this species from 'Mont Falcone' (= Mt Radoštak), not far from the site where we have recently collected it. As this area is poorly explored and because it is difficult to access, the species may be more widely distributed than believed earlier (see Gittenberger 1976).

\section{Habitat preference}

Unlike C. (L.) erika, this species is not bound to cave environments. We have found it on large limestone cliffs, mostly hidden in shady fissures.

\section{Remarks}

Due to the lack of material, Zallot et al. (2015) did not assign this species to any of the subgenera of Cochlostoma. The available anatomical and molecular data now unequivocally support its classification in Lovcenia.

Cochlostoma (Lovcenia) tropojanum Zallot, Fehér \& Gittenberger sp. nov. urn:Isid:zoobank.org:act:F986C8B8-F64C-41FE-9422-5B0FF2D749FB

Figs $5 \mathrm{C}, 6 \mathrm{C}, 10$

\section{Diagnosis}

Rather small, with a very slender, spotless and regularly ribbed shell, which has a poorly developed lip, inclined towards the front and broadening at the columellar side, before curving back and covering the umbilicus. In $C$. (L.) erika and C. (L.) dalmatinum, which are both larger, the columellar lobe differs; the latter species may also be distinguished by its prominent, irregular ribs, which are more uniform in C. (L.) tropojanum sp. nov. Cochlostoma (L.) lanatum sp. nov. differs by its regularly spaced, prominent, sharp ribs on the upper whorls. The geographically separate $C$. (L.) jakschae sp. nov. is conchologically similar but less slender, with an even narrower lip. It also differs in the female genitalia, i.e., by the less convoluted visceral oviduct. Moreover, C. (L.) jakschae sp. nov. has, relative to its shell size, a smaller protoconch.

\section{Material examined}

\section{Holotype}

ALBANIA: + (in ethanol), Tropojë District, gorge of Lumi i Tropojës, ca $14 \mathrm{~km} \mathrm{~N}$ of Tropojë, $965 \mathrm{~m}$ a.s.l., 42.4740 ${ }^{\circ}$ N, $20.1520^{\circ}$ E, 26 Jun. 2014, Angyal, Fehér and Grego leg. (NHMW 111638).

\section{Paratypes}

ALBANIA: 28 spec., same collection data as for holotype (NHMW 111248/8a+2ja, HNHM 99243/10a+3ja; GR/5a); 4 spec., ca $13 \mathrm{~km} \mathrm{~N}$ of Tropojë, $925 \mathrm{~m}$ a.s.1., $42.4692^{\circ} \mathrm{N}, 20.1554^{\circ} \mathrm{E}, 26$ Jun. 2014, Angyal, Fehér and Grego leg. (NHMW 111247/2ja, HNHM 99241/1a+1ja).

\section{Other material}

ALBANIA: Tropojë District, gorge of Lumi i Gashit, SW of Dretovë, $390 \mathrm{~m}$ a.s.1., $42.4009^{\circ} \mathrm{N}$, $20.0879^{\circ}$ E, 1 Jul. 2016, Erőss, Fehér, Szekeres and Grego leg. (NHMW 111654, HNHM 99865); Tropojë District, above Tropojë, at N foot of Mt Shkëlzen, in rocky grassland, $2020 \mathrm{~m}$ a.s.l., $42.4632^{\circ} \mathrm{N}, 20.1258^{\circ} \mathrm{E}, 6$ Jun. 2006, Barina leg. (HNHM 99871).

\section{Measurements}

Holotype: H 9.3 mm, W 3.8 mm, Wbw 3.3 mm, Ha 2.7 mm, Wa 2.7 mm.

Paratypes $(\mathrm{N}=12)$ : H 7.7-9.3 mm, W 3.4-4.0 mm, Wbw 2.8-3.2 mm, Ha 2.2-2.8 mm, Wa 2.1-2.9 mm. 


\section{Description}

SHELL. Small, with $81 \frac{1}{2}$ whorls, H/W ratio 2.8. The initial 2.4-2.5 whorls form the protoconch, which is smooth for only the initial $0.3-0.5$ whorl and finely ribbed with narrowly spaced riblets further on. The spotless shell is light yellowish. The teleoconch whorls are convex $(\mathrm{Rr}=1.24)$ with whitish, rounded, moderately developed ribs. The ribs are regularly spaced, without any variation between the upper whorls and the body whorl. The ribbing is still present on the final part of the body whorl, approaching the aperture. The aperture is relatively small $(\mathrm{Ha} / \mathrm{H}=0.19-0.20)$, with a poorly developed lip, inclined towards the front. The lip is broadened at the columellar side before curving back and covering the umbilicus. The body whorl has a small external lobe.

Female GENITALIA. Bursa copulatrix large, with a pedunculus connected proximally; its proximal lobe clearly smaller than the distal one. Short seminal receptacle, confined to the ventral side of the body and connected with the pedunculus without a distal oviduct. The 3-4 wide and small loops of the visceral oviduct are situated over the apex of the seminal receptacle. The junction of the uterine gland and the copulatory duct is moderately far from the connection between the seminal receptacle and the pedunculus of the bursa.

Male genitalia. The penis is longer than the body and thin, with a tapering tip. The spermiduct is narrowly twisted. The body spermiduct is straight. There is a sharp and long groove, ending in a wellformed sperm pocket, delimited on the frontal side by an ascending sperm funnel.

\section{Etymology}

This species is named after the Tropojë Valley, its type locality.

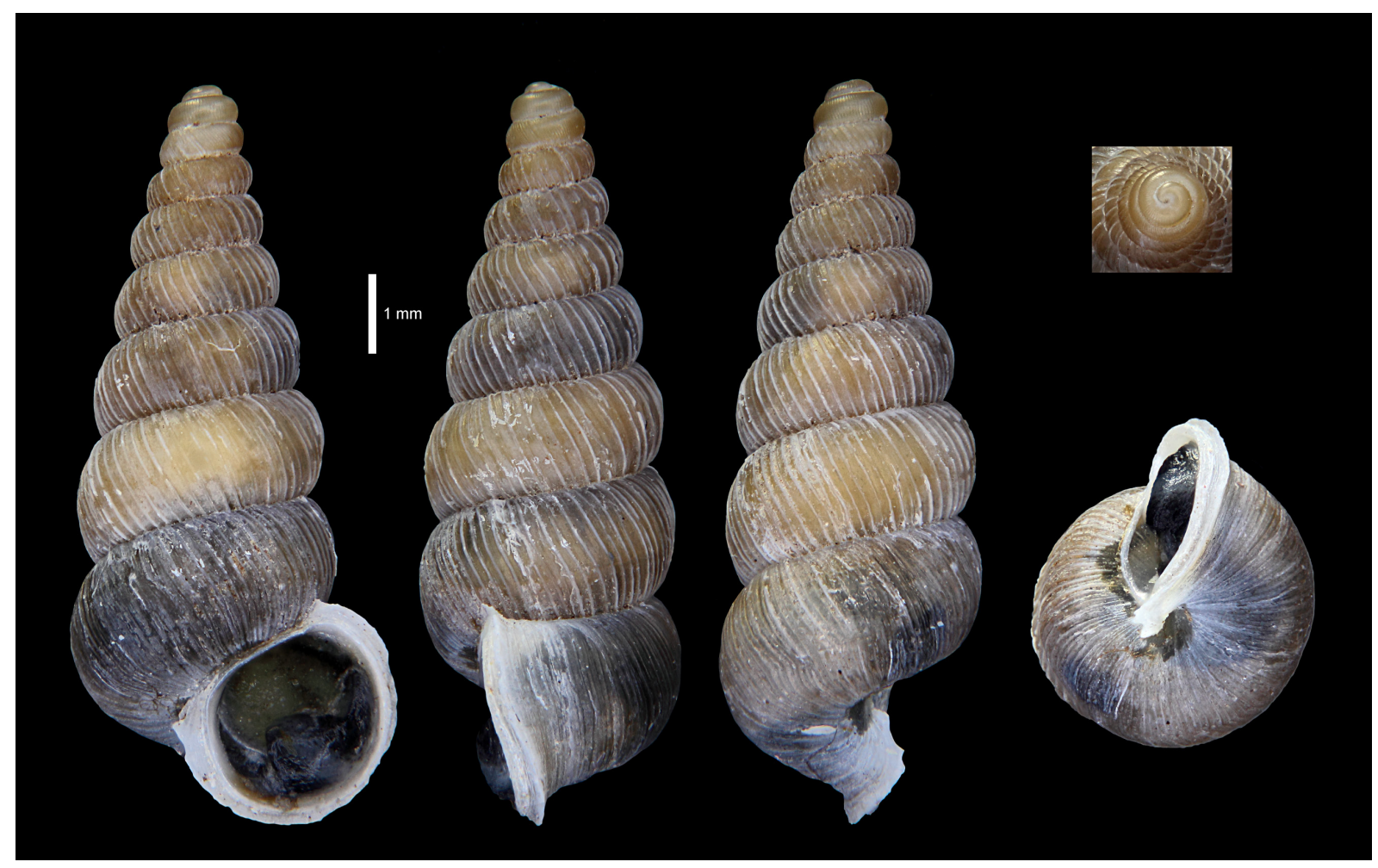

Fig. 10. Cochlostoma (Lovcenia) tropojanum Zallot, Fehér \& Gittenberger sp. nov., holotype, Tropojë Valley, Albania (NHMW 111638). 


\section{Distribution}

Mount Shkëlzen in the eastern part of the Prokletije Mts in NE Albania. Known from four nearby locations.

\section{Habitat preference}

Like most species of Cochlostoma, these are obligate rock-dwelling snails that can be found on the surface of limestone cliffs or under boulders on rocky alpine grasslands.

Cochlostoma (Lovcenia) jakschae Zallot, Fehér \& Gittenberger sp. nov. urn:1sid:zoobank.org:act:BBA8F11F-4FAD-4049-A685-1C2CBF95B5E2

Figs 5D, 6D1-D2, 11

\section{Diagnosis}

The smallest species of Cochlostoma (Lovcenia), differing from both C. (L.) dalmatinum and $C$. (L.) lanatum sp. nov. by the more regular, narrowly spaced, rather prominent ribs. The apertural lip is narrower and less conspicuously curved at the columellar side than in the consubgeneric species. The conchologically most similar species, $C$. (L.) tropojanum sp. nov., differs by its relatively larger protoconch and, in the female genitalia, by the less conspicuously convoluted visceral oviduct.

\section{Material examined}

Holotype

MACEDONIA: + (in ethanol), Ohrid District, Galičica Mts., Bugarska Peak, E side, $1795 \mathrm{~m}$ a.s.l., $41.0037^{\circ} \mathrm{N}, 20.8470^{\circ} \mathrm{E}, 16$ Oct. 2014, Fehér, Haring, Jaksch and Sattmann leg. (NHMW 111649).

\section{Paratypes}

MACEDONIA: 9 spec., same collection data as for holotype (NHMW 111651/4+4a+1ja); 4 spec., ca $200 \mathrm{~m}$ N of Bugarska Peak, $1795 \mathrm{~m}$ a.s.1., $41.0051^{\circ} \mathrm{N}, 20.8462^{\circ} \mathrm{E}, 16$ Oct. 2014, Fehér, Haring, Jaksch and Sattmann leg. (NHMW 111249/2a+2ja); 1 spec., ca $300 \mathrm{~m}$ W of Bugarska Peak, $1735 \mathrm{~m}$ a.s.1., $41.0046^{\circ}$ N, $20.8432^{\circ}$ E, 16 Oct. 2014, Fehér, Haring, Jaksch and Sattmann leg. (NHMW 111650).

\section{Other material}

ALBANIA: Shkodër District, Qafa e Pejës, N of Okol, 1700 m, 42.4332 ${ }^{\circ}$ N, 19.7671 E, 6 Jul. 2003, Erőss, Fehér, Kontschán and Murányi leg. (HNHM 97221); path from Qafa e Pejës to Maja e Harapit, 1800 m a.s.1., 42.4431 ${ }^{\circ}$ N, $19.7637^{\circ}$ E, 1 Jun. 2005, Barina, Murányi, Pifkó leg. (HNHM 94927).

\section{Measurements}

Holotype: H 7.3 mm, W 3.4 mm, Wbw 2.8 mm, Ha 2.4 mm, Wa 2.3 mm.

Paratypes $(\mathrm{N}=10)$ : H 6.7-7.7 mm, W 3.2-3.6 mm, Wbw 2.7-3.0 mm, Ha 2.1-2.6 mm, Wa 1.9-2.5 mm.

\section{Description}

SHELL. Small, with $7 \frac{1}{2}-81 / 2$ whorls (H/W ratio $2.42-2.57$ ). The initial 2.4 whorls form the protoconch, which is smooth for the first $0.5-0.7$ whorl and then finely costulate with closely spaced riblets. The protoconch is relatively large $\left(\mathrm{Dp} / \mathrm{D} 4^{\text {th }}=0.73\right)$. The shell is more or less dark horn-brown, without spots. The teleoconch whorls are costate, with whitish, slightly irregular in height, rounded ribs. The ribs are quite regularly and narrowly spaced, with 9-10 ribs per mm both on the $4^{\text {th }}$ whorl and on most of the body whorl. The ribbing is less prominent and denser on the last part of the body whorl approaching the aperture. The peristome is moderately developed; the lip broadens at the columellar side before curving 
increasingly back and covering the umbilicus. While approaching the aperture, the body whorl enlarges, while forming a moderately developed external lobe.

Female Genitalia. Bursa copulatrix very large, with a more or less posterior connection of the pedunculus. The short seminal receptacle is confined to the ventral side of the body. The tortuous loops of the visceral oviduct are situated over the apex of the seminal receptacle. The junction of the uterine gland and the copulatory duct is moderately far from the connection between the distal oviduct and the pedunculus.

\section{Etymology}

This species is named after Ms Katharina Jaksch-Mason (NHMW) who found the first individual of this species at Bugarska Peak.

\section{Distribution}

This species is known from two mountain ranges that are nearly $200 \mathrm{~km}$ apart, i.e., the Galičica Mts in southwestern Macedonia, Ohrid District, and the Prokletije (= Bjeshkët e Nemuna) Mts in northern Albania. It occurs at altitudes above $1700 \mathrm{~m}$. The former area is the southernmost occurrence known for the subgenus Lovcenia.

\section{Habitat preference}

Like most species of Cochlostoma, this is an obligate rock-dwelling snail that can be found on limestone cliffs or under boulders on rocky alpine grasslands.

\section{Remarks}

The molecular analyses confirm that the morphologically similar but geographically distant populations of the Bugarska Peak and the Pejë Pass are indeed conspecific.

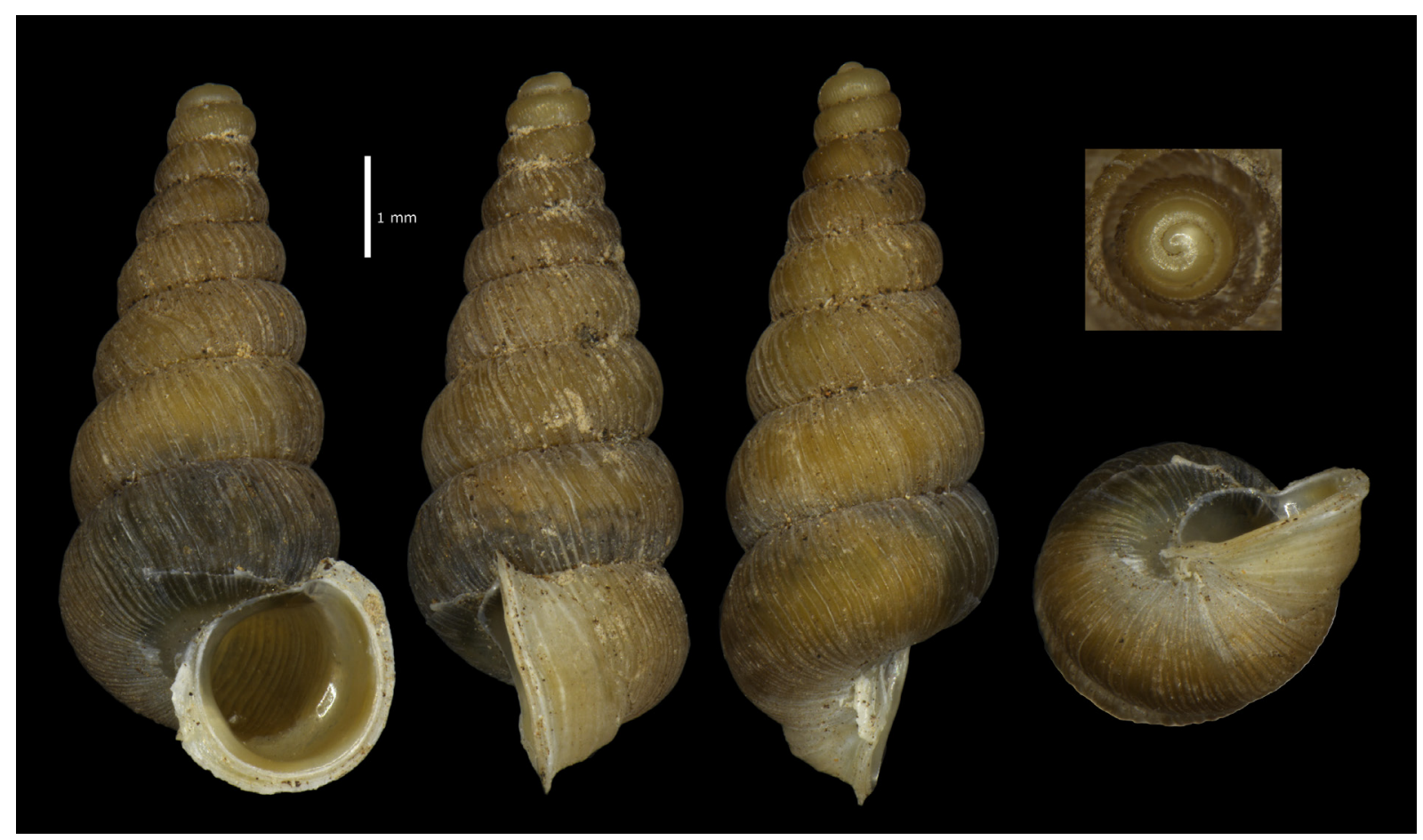

Fig. 11. Cochlostoma (Lovcenia) jakschae Zallot, Fehér \& Gittenberger sp. nov., holotype, Bugarska Peak, Macedonia (NHMW 111649). 
Cochlostoma (Lovcenia) lanatum Zallot, Fehér \& Gittenberger sp. nov. urn:lsid:zoobank.org:act:E615F65C-B3DC-4978-883C-4D10A06606E6

Figs $5 \mathrm{E}, 6 \mathrm{E}, 12$

Cochlostoma (Lovcenia) sp. - Zallot et al. 2015: 80.

\section{Diagnosis}

Shell without spots or color bands, relatively large and slender, with sharp, regularly spaced ribs on the upper whorls; ribs less sharp and more narrowly spaced on the lower whorls.

\section{Material examined}

\section{Holotype}

ALBANIA: ${ }^{\circ}$, Malësia District, SW slope of Mali e Veleçikut, Shpellë e Deleve, NW of Razëm, $1300 \mathrm{~m}$ a.s.l., limestone rock within cave, $42.3576^{\circ} \mathrm{N}, 19.5269^{\circ}$ E, 28 Jun. 2016, Erőss, Fehér, Szekeres and Grego leg. (HNHM 102806).

\section{Paratypes}

ALBANIA: 129 spec., same collection data as for holotype (NHMW 111652/7+ 12fr. $+19 \mathrm{a}+6 \mathrm{ja}$; GR/38+2fr; HNHM 99861/6+13fr.+26a); 1 o, same locality as holotype, 16 Oct. 2011, Gittenberger leg.

\section{Measurements}

Holotype: H 10.5 mm, W 4.6 mm, Wbw 3.8 mm, Ha 3.4 mm, Wa $3.1 \mathrm{~mm}$.

Paratypes $(\mathrm{N}=12)$ : H 8.4-9.5 mm, W 3.9-4.4 mm, Wbw 3.2-3.5 mm, Ha 2.7-3.1 mm, Wa 2.5-3.2 mm.

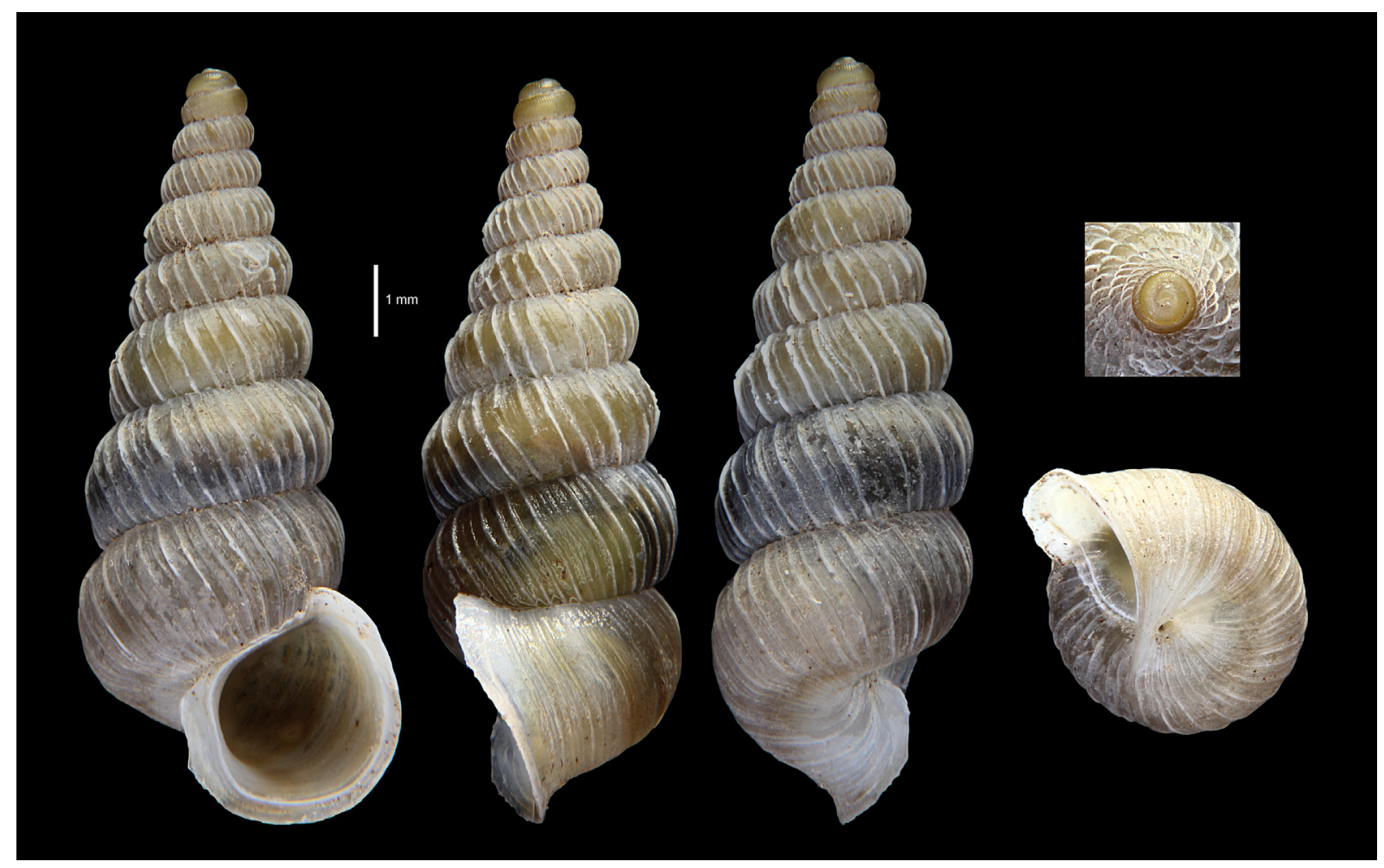

Fig. 12. Cochlostoma (Lovcenia) lanatum Zallot, Fehér \& Gittenberger sp. nov., holotype, Deleve Cave, Albania (HNHM 102806). 


\section{Description}

SHELL. Rather large and slender, with $81 \frac{1}{2}-9^{1 / 4} 4$ whorls (H/W ratio 2.84). The apical 2.2 whorls form the protoconch, which is smooth for only the initial 0.2 whorl and finely ribbed with close riblets further on. The shell is more or less light horn-brown, without spots. The teleoconch is sculptured with rather prominent, sharp ribs, which are widely spaced on the upper whorls and increasingly more narrowly spaced and less sharp towards the aperture. The aperture has a moderately developed lip, enlarged at the columellar lobe, which is abruptly bent inwards to cover the umbilicus. While approaching the aperture, the body whorl abruptly enlarges, forming a rather prominent external lobe.

Female genitalia. Bursa copulatrix large, with a pedunculus connected proximally; its proximal lobe smaller that the distal one. The short seminal receptacle is confined to the ventral side of the body, under (ventrally) the bursa copulatrix. The loops of the visceral oviduct are situated over the apex of the seminal receptacle. The junction of the uterine gland and the copulatory duct is far away from the connection between the pedunculus of the bursa and the distal oviduct.

\section{Distribution}

This species is only known from its type locality, the Deleve Cave on the southwestern slope of Mount Veleçik in northern Albania.

\section{Habitat preference}

Like the majority of known species of Cochlostoma, this is an obligate rock-dwelling snail. It was found in the twilight zone inside the Deleve Cave. Though little is known about its ecological requirements, it may be restricted to the epigean environment, like C. (L.) erika (i.e., subtroglophile in the sense of Sket 2008). At the Deleve Cave, its niche partitioning with Cochlostoma (Auritus) roseoli (A.J. Wagner, 1901) is similar to that of C. (L.) erika and C. (A.) auritum at the Popovo Cave in Montenegro.

\section{Remarks}

Zallot et al. (2015) assigned this species to Cochlostoma (Lovcenia), but with only one male specimen available, its systematic status remained difficult to judge. The shell morphology, in particular the protoconch sculpture, showed affinity to that of $C$. erika, whereas the molecular data suggested a status as a separate species. Since then, we have been able to collect and dissect female specimens. The structure of the female genitalia supports regarding it as a species on its own.

\section{Discussion}

As far as is known, the range of the subgenus Lovcenia extends from the Orjen Mts and the Njeguš Plateau (Montenegro) in the northwest to the Galičica Mts (Macedonia) in the south, with the central area of distribution in the Prokletije Mts.

Cochlostoma (Lovcenia) erika and C. (L.) lanatum sp. nov. are the only subtroglophile species known in the Cochlostomatidae. According to the trees based on concatenated COI, 16S and H3 sequences, these two taxa are not sister species, but relatively low supports of some branches indicate that relationships among the taxa of Lovcenia are not clarified beyond any doubt. Therefore, it seems feasible that the subtroglophile lifestyle evolved only once in this subgenus and was lost secondarily, but it is difficult to say whether the ancestral form of Lovcenia was already a subtroglophile species or not. Cochlostoma (L.) erika and $C$. (L.) lanatum sp. nov. occur syntopically with other large cochlostomatid species, namely $C$. (A.) auritus and C. (A.) roseoli. Snails of small species of Cochlostoma (e.g., of the subgenera Wagneriola Zallot et al., 2015 or Turritus Westerlund, 1883) and snails of large congeneric species often co-occur, but only very rarely are two large-sized species found syntopically. 


\section{Acknowledgements}

The authors are grateful to Dorottya Angyal, Tamás Deli, Michael Duda, Zoltán Erőss, Jozef and Maroš Grego, Elisabeth Haring, Katharina Jaksch-Mason, Dávid Murányi, Jenő Kontschán, Helmut Sattmann and Miklós Szekeres, who assisted during multiple field trips to the Balkans, and to Christoph Leeb for his help with the laboratory work.

This study was partly supported by the Austrian Research Fund (grant no. FWF P 26581- B25).

\section{References}

Anisimova M., Gil M., Dufayard J.-F., Dessimoz C. \& Gascuel O. 2011. Survey of branch support methods demonstrates accuracy, power, and robustness of fast likelihood-based approximation schemes. Systematic Biology 60: 685-699. https://doi.org/10.1093/sysbio/syr041

Bank R.A. 1988. Revision der nordostitalienischen Arten und Unterarten der Gattung Cochlostoma Jan, 1830 (Gastropoda Prosobranchia: Cyclophoridae). Basteria 52 (4/6): 151-170.

Colgan D.J., Ponder W.F. \& Eggler P.E. 2000. Gastropod evolutionary rates and phylogenetic relationships assessed using partial 28S rRNA and histone H3 sequences. Zoologica Scripta 29: 29-63.

https://doi.org/10.1046/j.1463- 6409.2000.00021.x

Duda M., Sattmann H., Haring E., Bartel D., Winkler H., Harl J. \& Kruckenhauser L. 2011. Genetic differentiation and shell morphology of Trochulus oreinos (Wagner, 1915) and Trochulus hispidus (Linnaeus, 1758) (Pulmonata: Hygromiidae) in the northeastern Alps. Journal of Molluscan Studies 77: 30-40. https://doi.org/10.1093/mollus/eyq037

Fehér Z. 2004. A revision of the genus Cochlostoma, subgenus Titanopoma (Gastropoda, Caenogastropoda, Cochlostomatidae), in particular the forms occurring in Albania. Basteria 68: 25-44.

Fehér Z., Eröss Z. \& Varga A. 2001. Contributions to the knowledge of the Albanian Cochlostoma fauna (Gastropoda: Cyclophoridae). Schriften zur Malakozoologie 17: 71-78.

Folmer O., Black M., Hoeh W., Lutz R. \& Vrijenhoek R. 1994. DNA primers for amplification of mitochondrial cytochrome c oxidase subunit I from diverse metazoan invertebrates. Molecular Marine Biology and Biotechnology 3: 294-299.

Gittenberger E. 1976. Vier wenig bekannte troglophile Schneckenarten aus Montenegro. Zoologische Mededelingen 49 (21): 273-283.

Hall T.A. 1999. BioEdit: A user-friendly biological sequence alignment editor and analysis program for Windows 95/98/NT. Nucleic Acids Symposium Series 41: 95-98.

Harl J., Páll-Gergely B., Kirchner S., Sattmann H., Duda M., Kruckenhauser L. \& Haring E. 2014. Phylogeography of the land snail genus Orcula (Orculidae, Stylommatophora) with emphasis on the Eastern Alpine taxa: speciation, hybridization and morphological variation. BMC Evolutionary Biology 14: e223. https://doi.org/10.1186/s12862-014-0223-y

Hoang D.T., Chernomor O., Haeseler A. von, Minh B.Q. \& Vinh L.S. 2017. UFBoot2: Improving the ultrafast bootstrap approximation. Molecular Biology and Evolution 35: 518-522.

https://doi.org/10.1093/molbev/msx281

Jaeckel S.G., Klemm W. \& Meise W. 1957. Die Land- und Süßwasser-Mollusken der nördlichen Balkanhalbinsel. Abhandlungen und Berichte aus dem Staatlichen Museum für Tierkunde in Dresden 23: 141-205. 
Kalyaanamoorthy S., Quang Minh B., Wong T.K.F., Haeseler A. von \& Jermiin L.S. 2017. ModelFinder: Fast model selection for accurate phylogenetic estimates. Nature Methods 14: 587-589.

https://doi.org/10.1038/nmeth.4285

Katoh K. \& Standley D.M. 2013. MAFFT multiple sequence alignment software version 7: improvements in performance and usability. Molecular Biology and Evolution 30: 772-780.

https://doi.org/10.1093/molbev/mst010

Kobelt W. 1902. Mollusca. Cyclophoridae. Das Tierreich 16: 1-663.

Kobelt W. 1907. Iconographie der Land- \& Süsswasser-Mollusken mit vorzüglicher Berücksichtigung der europäischen noch nicht abgebildeten Arten von E. A. Rossmässler, Neue Folge 13 (1-2): 1-68. Kreidel, Wiesbaden. Available from https://biodiversitylibrary.org/page/16302427 [accessed 8 Aug. 2018].

Nguyen L.-T., Schmidt H.A., Haeseler A. von \& Minh B.Q. 2015. IQ-TREE: A fast and effective stochastic algorithm for estimating maximum-likelihood phylogenies. Molecular Biology and Evolution 32: 268-274. https://doi.org/10.1093/molbev/msu300

Páll-Gergely B., Fehér Z., Hunyadi A. \& Asami T. 2015. Revision of the genus Pseudopomatias and its relatives (Gastropoda: Cyclophoroidea: Pupinidae). Zootaxa 3937 (1): 1-49.

https://doi.org/10.11646/zootaxa.3937.1.1

Palumbi S.R. 1996. PCR and molecular systematics. In: Hillis D., Moritz C. \& Mable B. (eds) Molecular Systematics: 205-248. $2^{\text {nd }}$ edition. Sinauer Press, Sunderland.

Pfeiffer L. 1863. Beschreibung eines neuen Pomatias. Malakozoologische Blätter 10: 136-137.

Rambaut A., Suchard M.A., Xie D. \& Drummond A.J. 2014. Tracer ver. 1.6.

Available from http://beast.bio.ed.ac.uk/Tracer [accessed 8 Aug. 2018].

Ronquist F., Teslenko M., van der Mark P., Ayres D.L., Darling A., Höhna S., Larget B., Liu L., Suchard M.A. \& Huelsenbeck J.P. 2012. MRBAYES 3.2: efficient Bayesian phylogenetic inference and model choice across a large model space. Systematic Biology 61: 539-542.

https://doi.org/10.1093/sysbio/sys029

Sket B. 2008. Can we agree on an ecological classification of subterranean animals? Journal of Natural History 42 (21-22): 1549-1563. https://doi.org/10.1080/00222930801995762

Schütt H. 1977. Revision der griechischen Cochlostoma. Archiv für Molluskenkunde 108 (1-3): 17-35.

Tamura K., Stecher G., Peterson D., Filipski A. \& Kumar S. 2013. MEGA6: Molecular Evolutionary Genetics Analysis version 6.0. Molecular Biology and Evolution 30: 2725-2729.

https://doi.org/10.1093/molbev/mst197

Thomsen P.F., Elias S., Gilbert M.T.P., Haile J., Munch K., Kuzmina S., Froese D.G., Sher A., Holdaway R.N. \& Willerslev E. 2009. Non-destructive sampling of ancient insect DNA. PLoS ONE 4 (4): e5048. https://doi.org/10.1371/journal.pone.0005048

Trifinopoulos J., Nguyen L.T., Haeseler A. von \& Minh B.Q. 2016. W-IQ-TREE: a fast online phylogenetic tool for maximum likelihood analysis. Nucleic Acids Research 44 (W1): W232-W235. https://doi.org/10.1093/nar/gkw256

Uit de Weerd D.R. \& Gittenberger E. 2013. Phylogeny of the land snail family Clausiliidae (Gastropoda: Pulmonata). Molecular Phylogenetics and Evolution 67: 201-216.

https://doi.org/10.1016/j.ympev.2013.01.011

Wagner A.J. 1897. Monographie der Gattung Pomatias Studer. Denkschriften der kaiserlichen Akademie der Wissenschaften, mathematisch-naturwissenschaftliche Classe 64: 565-632. 
Wagner A.J. 1906. Neue Formen und Fundorte der Genera Pomatias Studer und Auritus Westerlund. Nachrichtsblatt der deutschen malakozoologischen Gesellschaft 38 (2-3): 92-101, 121-140. Available from https://biodiversitylibrary.org/page/15599307 [accessed 8 Aug. 2018].

Walderdorff R. 1864. Systematisches Verzeichniss der im Kreise Cattaro (Süd-Dalmatien) mit Ausnahme der Biela-Gora und in einigen angrenzenden Theilen von Montenegro und türkisch Albanien vorkommenden Land- und Süsswasser-Mollusken. Verhandlungen der kaiserlich-königlichen zoologisch-botanischen Gesellschaft in Wien 14: 503-514.

Welter-Schultes F.W. 2012. European Non-Marine Molluscs, a Guide for Species Identification: A1-A3, 1-679, Q1-Q78. Planet Poster Editions, Göttingen, Germany.

Zallot E. 2002. Alcune note sul genere Cochlostoma Jan, 1830 (Gastropoda, Prosobranchia) in Friuli (Italia nord-orientale). Gortania 24: 93-113.

Zallot E., Groenenberg D.S.J., De Mattia W., Fehér Z. \& Gittenberger E. 2015. Genera, subgenera and species of the Cochlostomatidae (Gastropoda, Caenogastropoda, Cochlostomatidae). Basteria 78 (4-6): 63-88.

Zilch A. 1958. Die Typen und Typoide des Natur-Museums Senckenberg, 21: Mollusca, Cyclophoridae, Craspedopominae-Cochlostominae. Archiv für Molluskenkunde 87 (1/3): 53-76.

Manuscript received: 28 March 2018

Manuscript accepted: 16 July 2018

Published on: 2 October 2018

Topic editor: Rudy Jocqué

Section editor: Kurt Jordaens

Desk editor: Danny Eibye-Jacobsen

Printed versions of all papers are also deposited in the libraries of the institutes that are members of the EJT consortium: Muséum national d'Histoire naturelle, Paris, France; Botanic Garden Meise, Belgium; Royal Museum for Central Africa, Tervuren, Belgium; Natural History Museum, London, United Kingdom; Royal Belgian Institute of Natural Sciences, Brussels, Belgium; Natural History Museum of Denmark, Copenhagen, Denmark; Naturalis Biodiversity Center, Leiden, the Netherlands; Museo Nacional de Ciencias Naturales-CSIC, Madrid, Spain; Real Jardín Botánico de Madrid CSIC, Spain; Zoological Research Museum Alexander Koenig, Bonn, Germany. 